PUBLIC ART: CONTEXT \& PROCESS IN SAN LUIS OBISPO, CA

\author{
A Thesis \\ presented to \\ the Faculty of California Polytechnic State University, \\ San Luis Obispo
}

\begin{abstract}
In Partial Fulfillment
of the Requirements for the Degree

Master of City \& Regional Planning
\end{abstract}

by

Kristin Ann Kiefer

June 2014 
(C) 2014

Kristin Ann Kiefer

ALL RIGHTS RESERVED 


\section{COMMITTEE MEMBERSHIP}

TITLE:

AUTHOR:

DATE SUBMITTED:

COMMITTEE CHAIR:

COMMITTEE MEMBER:

COMMITTEE MEMBER
Public Art: Context \& Process

In San Luis Obispo, CA

Kristin Ann Kiefer

June 2014

Associate Professor of City and Regional Planning

Michael Lucas, $\mathrm{PhD}$

Associate Professor of Architecture

Daniel I. Dove, $\mathrm{PhD}$

Associate Professor of Visual Arts 


\section{ABSTRACT \\ Public Art: Context \& Process in San Luis Obispo, CA}

\section{Kristin Kiefer}

Public spaces are noted by historians, philosophers, planners, etc as being the lifeblood of civic centers, spaces that bring people in community together for a myriad of reasons. Recalling the ancient Agricola's of ancient Greece to the modern version of malls and pedestrian plazas, these spaces are where social interactions occur, ideas are spread, and are open for all people to enjoy. Beautifying these spaces with public art and well-thought out design encourage the use of these spaces and work to empower those who use them. While the mode in which public art populates public spaces has changed, the notion that they exist to benefit a public good, act as a civilizer, create character and a distinct environment endures. The idea of public art is unique and is noted for doing something that neither a public space without art nor a museum with art can do: it can capture the eye and mind of individuals passing through public spaces. Making people pay attention to the civic environment around them, creating a sense of "civic vitality" in cities, towns and communities. Public art prompts vital questions about our environment and ourselves, encouraging a broad range of learning opportunities. Public installations of art celebrate culture and the environment, providing connections to history and the natural world. It makes space interesting and different from another. Public artwork is celebrated and condemned for its ability to challenge, delight, educate, and illuminate. Establishing written policies and programs for the arts solidify their place in communities, enacting a set of codes and a process for which artistic endeavors are woven into the complex urban landscape.

The role public art plays in communities is unique in the marrying of two very different sectors of civic life: art and aesthetics with the political planning process. This study examines how political decisions impact the installation process for public artwork in cities. How do written policies and programs support opportunities for installations, ways to empower the community and brighten the streetscape, and where are there gaps in knowledge and information that make the process more convoluted and difficult to navigate? Through studying the public art installation process in the City of San Luis Obispo from the perspective of the administrators working with the public art programs and policies and comparing the process with the ways in which the community is empowered by public art a number of recommendations are made to increase transparency and encourage artistic opportunities in the town with an already robust Public Art Program. 
TABLE OF CONTENTS

Page

LIST OF FIGURES vii CHAPTER

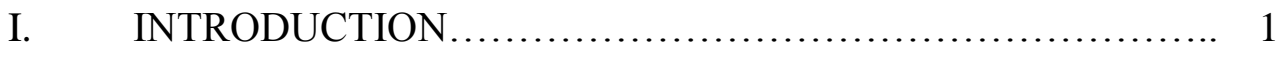

Statement of Problem................................ 1

II. THEORETICAL FRAMEWORK/

LITERATURE REVIEW ..................................... 3

Historic Examples of Art in Public, Social Sphere........... 4

Art and Architecture of the Roman Empire:

"monolithic cultural assumptions".................. 4

Medieval Europe.................................. 7

Italian Renaissance.............................. 7

Impressionism and the Industrial Revolution........ 8

Corporate art replaces the role of the church............. 9

Public Art as a tool.................................... 10

Public art is "Good for Society"................... 11

History of Public Art in the US -

A Brief History of Public Art Policy \& Programming.......... 11

"New Public Art" of the 1980's- Art \& Function.......... 16

Controversies in Public Art and Civic Engagement........... 18

Current Examples in Public Art......................... 24

New Functions of Public Art....................... 24

Art Initiatives....................................... 31

III. METHODOLOGY......................................... 35

Research Question.................................... 35 
Research Design................................. 35

IV. FINDINGS ............................................ 37

Government \& Art: Processes \& Expectations................. 37

The Public Art Installation Process in San Luis Obispo, CA..... 38

The Public Art \& Procedures Manual................ 38

Expert Interviews............................. 45

A. Director of Arts Obispo Interview.................. 45

Arts Obispo \& the public art installation process... 47

Potential for Future Projects.................. 49

B. Department \& Public Art Program Manager

Of the Parks \& Recreation Department Interview... 49

The Public Art Installation Process.................. 50

C. Senior Planner Community Development

Department Interview......................... 54

\#Public Art Is Art After Dark "\#Public Art Is"

Community Interaction....................... 57

V. CONCLUSIONS ....................................... 61

Closing Remarks \& Recommendations................ 61

BIBLIOGRAPHY ....................................... 66

APPENDICES

A. Art After Dark \#PublicArtIs Activity Boards............ 69

B. Tabulations of All Responses from

\#PublicArtIs Activity............................. 77 


\section{LIST OF FIGURES}

Figures Page

1. Trajan's Column, Rome, Italy.............................. 5

2. Detail of relief on Trajan's Column, Rome, Italy .............. 5

3. Union Station, Tacoma, Washington...................... 9

4. "Pylons," Martin Puryear, 1995. Battery Park City, New York........ 16

5. "Tilted Arc", 1981 Richard Serra. Federal Plaza, Manhattan, New York 20

6. Neon for La Jolla, Stephen Anotonakos, 1984.................... 21

7. Neons for the Tacoma Dome, Stephen Antonakos, 1980,

Tacoma, Washington (prior to removal). ........................ 22

8. "W", Colin Gray, 2006, Santa Barbara, California................... 23

9. Pianos on State Street, collaboration of artists, 2013, Santa Barbara, CA 26

10. "Tour Paris 13”, collaboration of artists, 2013. Paris, France.......... 27

11. "Before I Die", Candy Chang, 2011. New Orleans, Louisiana.......... 29

12. "I Wish This Was", Candy Chang, 2010. New Orleans, Louisiana...... 30

13. "I Wish This Was", Candy Chang, 2010. New Orleans, Louisiana...... 30

14. "Ballroom Luminoso," Joe O’Connell \& Blessing Hancock, 2013, San Antonio, TX. ...................................... 33

15. City Funded Public Art Process flow chart......................... 41

16. Privately Funded Public Art process flow chart.................... 42

17. Matching Grants for Public Art process flow chart.................. 44

18. "Puck," Elizabeth McQueen, 2002. San Luis Obispo, CA.............. 46

19. "Web of Life," Sandra Kay Johnson, 1999. San Luis Obispo, CA........ 46

20. Painted Box Art at Santa Rosa \& Palm Street, Colleen Gnos, San Luis Obispo, CA............................................. 48

21. Painted Box Art at Santa Rosa \& Monterey Street, Robert Maja, San Luis Obispo, CA.......................................... 48

22. "I Think Public Art..." et. al. Materials for Art After Dark

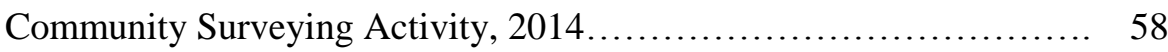

23. "\#PublicArtIs" board part of community surveying, 2014_.......... 59 


\section{CHAPTER I. Introduction}

Public art is a unique happening. It is the thread between art, extracted out of the formal museum setting, set against a rich urban landscape, entrenched in the domain of urban planners, policy makers, and bustling human interactions. Combining the artistic process with the political planning process creates a field that is a point of contention and controversy positioning urban policy procedures against free expression. The shape, form, and intent of situating art in urban centers has shifted over the centuries impacted by political powers, artistic movements, depression, war, and a myriad of other social factors, but regardless art has always had a part in shaping the urban environment around it. Several government sources agree that public art is most important to the life of cities and for the well-being of its residents. How art and planning are combined into a singular civic process is a unique relationship that brings into question ideals for urban aesthetics and the notion of service a public good.

This thesis aims to identify the historical role of urban art endeavors, identifying the established process for installing art into the fabric of the City of San Luis Obispo. The thesis identifies the public views towards public art installations, emphasizing what should be encouraged. In summation the thesis provides recommendations to aid the civic process for installing public artwork to be more inclusive of the many parties at play in the process. The theoretical framework and literature review that follows outlines the ways in which public art has shifted in approach, changing modes of appreciation, different funding mechanisms, and changes in the form artwork takes.

\section{Statement of Problem:}

The many differences regarding the priorities and expectations surrounding the role/implementation of public art impact where/why a piece of artwork is installed and how public art is appreciated. These priorities impact the process for installing public artwork. The goal is to study the existing policy \& procedures for installing public artwork and relate the 
process to how public art is perceived by the public for what it does for a community and how it should function. The civic structure for approving and installing artwork in San Luis Obispo involves the participation of several interested parties and stakeholders. To address these points of views the process involves multiple stages of approvals and community input. Understanding how each party is represented and their point of view conveyed is essential for a successful public art program. 


\section{CHAPTER II. Theoretical Framework/Literature Review}

The story of public art is a long, convoluted and interwoven history delving into theories regarding city and spatial planning, and the use of public spaces, cultural values, and several artistic movements. The following chapters chronicles the presence and function of artistic forms in cities, the formation of governmental programming to support artistic ventures, and the varying trends and opportunities for different art forms that populate urban landscapes.

Recognized art of nearly all cultures embraces a collective model, "indulging the differences among individuals as variant manifestations of a common spirit" (Hein, 1996). This common spirit fuels a demand for multiple opportunities for expression, a theme that has sustained time and place.

The celebrated treasures of Greece and Rome, as well as the Christian works of the Middle Ages and the age of the fresco that succeeded them, do not exalt the private vision of the individual artists so much as they bespeak the shared values and convictions of cultural communities, and are accordingly to be found in those edifices and open places where people regularly gather to commemorate those same values and convictions (Hein, 1996).

The theories articulating the relationships between public space, civic urbanity, and patterns of social behavior inform the ways in which space is designed, used, and decorated. Cities have evolved with advancements in technology, immigration, and other contextual factors. These factors allow for the weaving of an intricate tapestry of urban life. Much has been postulated about the use of public space by theorists and planners from the likes of Jane Jacobs, Kevin Lynch, Henri Lefebvre, and Pierre Bourdieu. Charles Landry introduces the theory of civic urbanity framed by a focus on: the shared commons, eco-consciousness, healthy urban planning, the notion of cultural literacy, and the intercultural city, the aesthetic imperative, creative city making, and an invigorated democracy. Ideas behind civic urbanity seek to align individual desires within a collective consciousness (“common spirit”) focusing on altruistic behavior outlining "responsibilities for 'us' and our joint world"' (Landry, 2013). These notions set the 
stage for discussing how public art impacts public space, impacting notions of social responsibility, planning, and aesthetics.

“The history of public art is most often told with an emphasis on the word 'art,' and very little consideration of the public context" (Finkelpearl, 2000). This research examines the historical context of how public art has shaped community space, beliefs, working historically as a political tool to exact dominance, and how public art has evolved. Throughout history, art has been used as a tool to convey messages to the masses. This theme remains a constant through centuries, where seats of power holders change, but art continues to be used as a tool for those who commission works and encourage its installation. The role of public artwork shifted in American cities post WWII to develop a language for "community-oriented" development working towards "healing wounds inflicted by the fragmentation and social segregation of contemporary public space” (Finkelpearl, 2000).

"Privacy was for centuries a private concept" (Hein, 1996). Historically, art had been consumed in a very private manner. Traditionally only the very wealthy could buy and "consume" artwork, but through various outlets such as monuments and architecture, art became more accessible to many publics. The purpose for the following research is to provide examples of the wide variety of types of public art and opportunities planned for it, not to provide a survey list of public art.

\section{Historic Examples of Art in Public, Social Spheres}

\section{Art and Architecture of the Roman Empire: "monolithic cultural assumptions"}

Art and architecture characteristic of the Roman Empire worked to visualize political agendas. Monumental architecture celebrated conquest, expansion, and power through civic structures for public use and enjoyment. The Romans proclaimed their victories and told the stories of their campaigns through grandiose monumental architecture and sculpture. (Gombrich, 
1995) War/battle monuments were very popular in both Republican and Imperial periods of the Roman Empire for these pieces exacted messages for the agenda of power holders. These works "educated" the public on the events of battles, the tragedies of war, and the victories, typically resulting in representations that glorified the events of war as told through the victor's bias. These monuments took the form of amphitheaters, baths, circuses, gardens, triumphal arches, porticos, and many other varieties transforming the streetscape of ancient cities into graphic retellings of power transfers. One of the most famous examples of these monuments is Trajan's column, a triumphal column in Rome, Italy, that celebrates Emperor Trajan's victory in the Dacian Wars. The column is famous for the spiral relief depicting epic war scenes between the Romans and Dacians. A personification of victory appears repeatedly throughout the frieze as a source of divine hope leading the

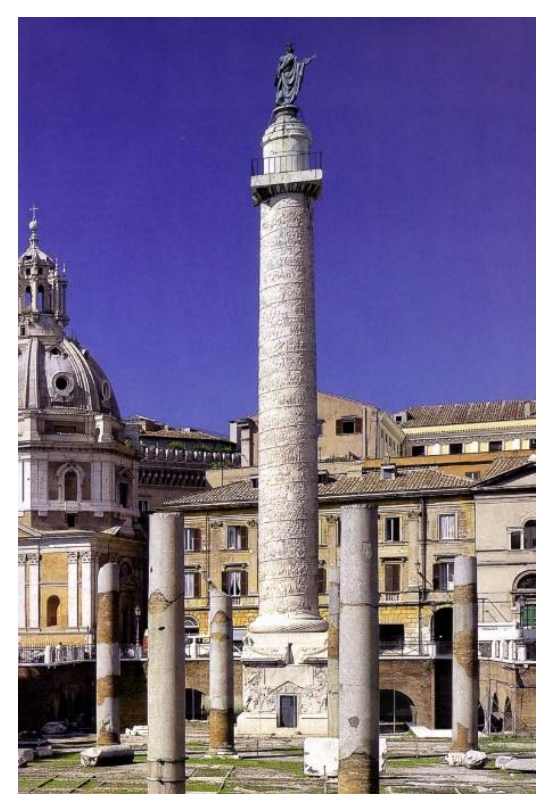

Figure 1: Trajan's Column, Rome, Italy.

Romans into battle. The purpose for this

columns and other monumental architecture pieces were forms of a traditional propaganda, glorifying the emperor's military exploits. The situation of this work in the heart of Trajan's Forum, a major common space for public use,

encourage public interaction.

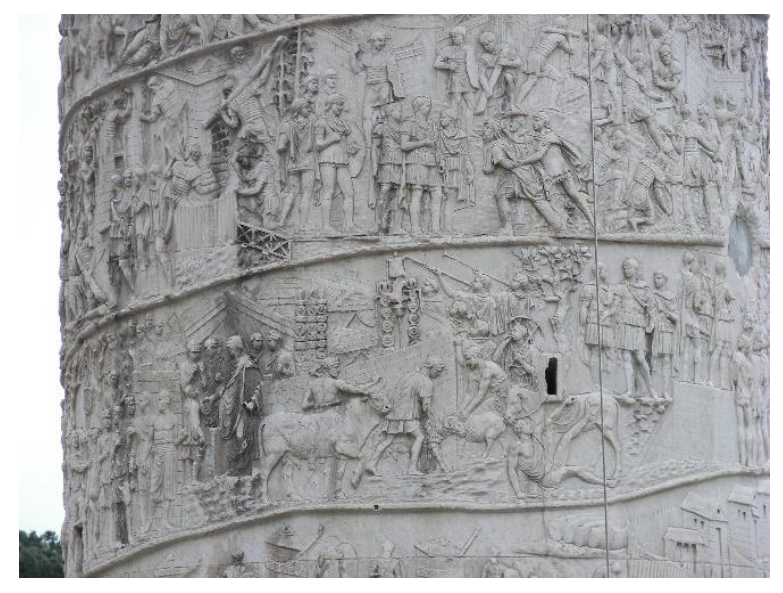

Another form of conquest utilized by ancient

Figure 2: Detail of relief on Trajan's Column, Rome, Italy. societies was using art as a tool for acquiring "culture." Aside from triumphal monuments, victories were also celebrated through the acquisition of the losing party's art and artistic 
knowledge. The Romans "adopted" art from the stretches of the empire, celebrating their victories in Africa, Spain, Greece, and in Asia Minor. The effects of Roman conquest meant that Egyptian obelisks were woven into Italian piazzas and a seamless appreciation of art, wherever it was created, characterized daily life for anyone experiencing the space from the ancient Romans to the modern tourist. These cultural conquests were responsible for ancient Romans appropriating and preserving many of the best surviving elements of the ancient world! Not only was culture acquired through the physical artworks created by other cultures, but throughout history the mastering of other culture's artistic styles was seen as a way of conquering other peoples (Gombrich, 1995). These forms of public artwork showed that aesthetic appreciation was fundamental to city life.

Historically the design of public spaces have defined the ways in which public interactions take place, and their context. The architecture of the Roman Forum as a public space invites a myriad of uses from festival celebrations to market spaces and other daily functions, combining the uses of art, entertainment, and daily life (Gombrich, 1995). The Coliseum/ Flavian Amphitheatre, a monument constructed for the entertainment of the masses, as part of pan et circuses, a theme developed to subdue the public and by keeping the masses entertained quelled uprisings. Intentions behind the construction of such a space was to provide public space for mass enjoyment and pride for a beautifully designed, colossal structure in their City. The monument now one of the most famous icons the world over was constructed during a time of peace and prosperity where more time was dedicated to aesthetics and enhancing the quality of life.

Years later when the dominant religion of the Roman Empire shifted from paganism to Christianity the connection/conversion of feats of architecture to religious uses came to mean that great works of art and architecture never went to disrepair. The partnership forged through the connections among art, the church, and government enabled the construction of incredible basilicas, cathedrals, and other architectural monuments revolutionizing building practices and 
attracting throngs of visitors to holy sites each year. For example, the Roman Pantheon, the world's largest unreinforced concrete dome, was originally constructed as a pagan temple, but had later been converted to a Church in the $7^{\text {th }} \mathrm{C}$ under the Byzantine Empire, thus preserving it from destruction in wars. The preservation of architecture and artworks instilled them as valuable parts of culture that enhance the urban landscape and never to be undervalued.

\section{Medieval Europe}

Gothic art was a style of medieval art that developed out of Northern France taking roots from Romanesque art in the $12^{\text {th }}$ Century. The church effectively used art and architecture as a way to communicate to the general population. Gothic art included many types of sculpture, panel painting, stained glass, fresco, and illuminated manuscripts, the earliest of these being monumental sculpture adorning the walls of Cathedrals and abbeys, typically being typological in form. The magnificent architecture of the Gothic Cathedrals set against pastoral landscapes created a dramatic contrast. The cathedrals served as a center for social interaction and religious purposes. Gothic art forms featured representations of stories of the Old and New Testaments as well as the lives of Saints'. The forms were unique for the infusion of emotion into a stylistic form. The period surrounding Gothic art was the birth of secular art with the rise of cities, the foundation of universities, increase in trade, the establishment of a money-based economy, and the creation of a bourgeois class who could afford to patronize the arts and commission works. The growth of cities established the place of trade guilds, groups formed to master their crafts and the art of creating works. Guilds began a longstanding tradition of organizations formed to develop and support artistic endeavors.

\section{Italian Renaissance}

Leading up to and during the Renaissance it was the role of artists, sculptors and painters to design Italian architecture and the city streets. These artists were responsible for designing the space in which public interactions took place. The period valued the works of Michelangelo and 
the like decorated civic buildings, public piazzas, churches, etc maintaining the view that art produced at the time was meant to inspire the public and be divine. During this time powerful families began commissioning art for "arts' sake" and for establishing a legacy. The patronage of "public" works of art in the Renaissance were installed for the benefit of a public good to enhance the quality of life that was reflected in the grandiose ideals of the connections of philosophy and art.

\section{Impressionism and the Industrial Revolution}

Art and science worked in ways to propel society forward. This "frenzy" can be seen in the scientific and social progress in the $18^{\text {th }}$ and $19^{\text {th }}$ Centuries allowed for great advancement across many social and technological barriers. The romanticism for this era is seen in the Impressionist works of artists to the likes of Claude Monet, Paul Cézanne, and Pierre Auguste Renoir. Products of this movement departed from traditional forms of painting to represent more vivid scenes in life and celebrating modernity in the visualization of the sensation of experiencing modernity. Loose, rapid brush strokes and employing the aid of photography were tropes for conveying changing ways of life. These pieces now focused on urban subject matters, especially scenes of Parisian leisure and entertainment, city parks, and suburban landscapes. Claude Monet's painting Arrival of the Normandy Train, Gare Saint-Lazare of 1877 reiterates the frenzy and excited nature surrounding the air of new possibilities made possible with new technology. This excited nature impacted the way in which people saw art and what it meant. 
This fascination with new forms of representation and new advancements in technology led to the advancement of the railroad system, bridges, and tunnels. Train stations in Europe and the United States became cultural hubs and prime centers for the artistic expression.

Tacoma, Washington's Union Station completed in 1911 is an example of magnificent BeauxArts architecture. At the time of

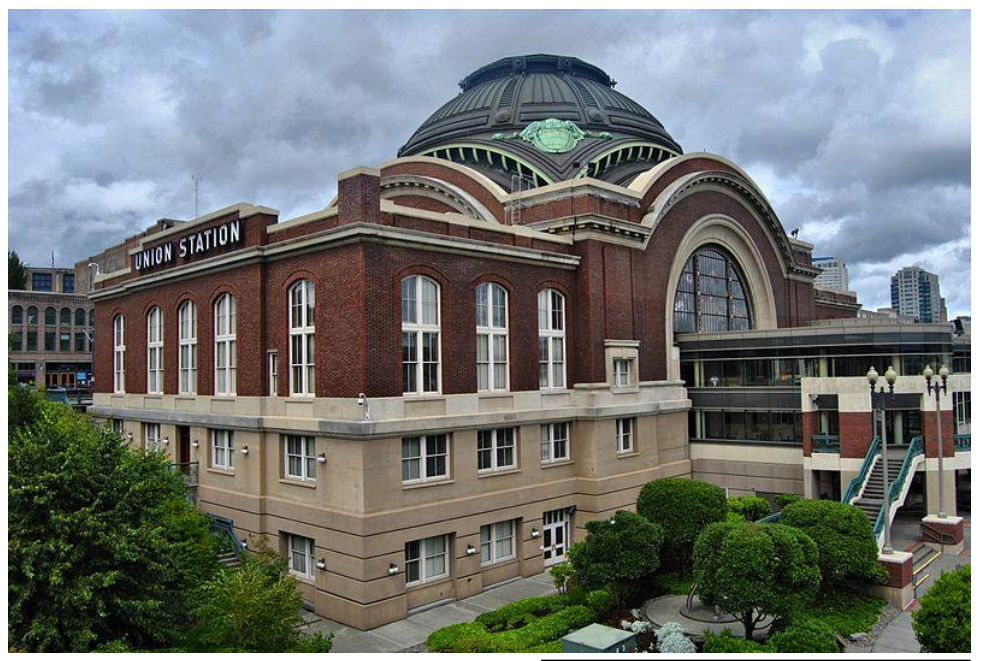
its construction the building was praised in the Tacoma Daily Ledger for being "the largest, most modern and in all ways the Figure 3: Union Station, Tacoma, Washington. most beautiful and best equipped passenger station in the Pacific Northwest." Today the building no longer is used as a functioning station, but rather holds courtrooms for the federal courts. Union Station is adorned with glasswork of world-famous, and Tacoma native artist Dale Chihuly. Even though the Beaux-Arts style of architecture was repeated world-wide, the structural form carried a greater meaning for local culture. While the architecture was not location specific, Union Station is a point of great civic pride for the city of Tacoma. It was listed in the National Register of Historic Places in 1974, and years later the entire Union Station Warehouse District was added to the Register as well. Today the Tacoma Public Arts Commission is working to create a public art walk through the Historic District.

\section{Corporate art replaces the role of the church}

Governments and civic leaders use the power of art to strengthen the unity that nourishes society. Their contracts with the artists survives as evidence of their intentions (Stokestad, 2008). The period between World War I and WWII was formative for an emerging institutionalized "American corporate culture of generosity," where the patronage of artistic endeavors could be 
associated with publically traded companies and various stakeholders (Kirchberg, 2004). This is exemplified in the philanthropic endeavors of Pierre S. du Pont, president of the DuPont Company and later chairman of General Motors. His role as one of the most influential and innovative American business leaders of the 1920's and inclusion of philanthropic activities as a cornerstone his business model shifted views of corporate intervention in the social sphere.

Pierre S. du Pont launched an educational reform movement in Delaware to address problems related to underfunding in the public school system. His involvement reflected a "longstanding paternalistic interest in the state of Delaware (Kirchberg, 2004). Efforts donated to numerous arts institutions, educational institutions, and other purposes. Du Pont's primary philanthropic goal was the improvement of the Delaware school system to have a statewide influence, the establishment of an art center with very broad human interests, representing the various cultural arts. These goals enacted an effort for "developing new standards of citizenship and enriching life, both individual and in the community affected" (Kirchberg, 2004). The goals were established in reaction to the "failure of Delaware to meet its responsibilities in providing art facilities for its citizens... The purpose (of a new art museum) is... to determine ways in which the arts can best serve the Community by developing (a) cultural and spiritual growth, (b) better citizens, (c) more effective educational methods, (d) trained artists, designers and craftsmen, (e) more valuable industrial products" (Kirchberg, 2004). This period spurred a spark for discussions for $\operatorname{art}(\mathrm{s})$ as an international symbol that marks civility and class. The United States, as a rising world power could not afford to not participate in the discussion.

\section{Public Art as a tool}

Governments and civil leaders used the power of public art and idealism to strengthen civic unity. Historically there was a class distinction between those who came into contact with art; where the upper class were the only ones who could buy/ consume art. A shift came about with monumental public art, established as a way for the working class to come into contact with 
artistic forms. The role of public art shifted from a predominantly "educational" one to one of actualizing an agenda.

\section{Public art is “Good for Society”}

Public art does more for a community than making an area more aesthetically pleasing. The Policy Studies Institute describes public art as beneficial because it contributes to local distinctiveness, attracts local investments, boosts cultural tourism, enhances land values, creates employment, increases use of urban spaces, and reduces vandalism (Sharp et al. 2005). The sentiments for the benefits of public art are also expressed by the Americans for the Arts foundation in their writing "Why Public Art Matters," "Public art humanizes the built environment and invigorates public spaces. It provides and intersection between past, present and future, between disciplines, and between ideas. Public art is freely accessible.

\section{History of Public Art in the US - A Brief History of Public Art Policy \& Programming}

The governmental support for providing art in urban centers rallied on the ideal of returning art and aesthetics to the American City. Government programs officially sanctioned the arts as significant contributors to our nation's 'well-being', and 'support for culture' was established as 'a legitimate government responsibility' (Knight, 2008). The New Deal and the National Endowment of the Arts laid the foundation for public art in metropolitan areas. The Roosevelt administration's New Deal produced a series of buildings, bridges, and murals as part of the economic programs between 1933 and 1936 responding to the social impacts of the Great Depression. Nearly thirty years later the first "Percent for Art" law in the United States passed Philadelphia's City Council in 1959 being called the "Aesthetic Ornamentation of City Structures." The establishment of a separate budget, one-percent of the construction costs of public buildings, an "art allocation" was mandatory. Michael von Maschziker, a sponsor of the bill, said: "Spread the message that fine arts must be returned to American architecture; that 
sterility and her handmaiden, monotony, must be banished from our avenues" (Finkelpearl, 2000). Later in 1965, the National Endowment for the Arts was created by President Johnson and the U.S. Congress. With the establishment of the NEA substantial federal tax-based funds were allocated for the arts at the state and local levels. The NEA established its Art-in-Public-Places (A-I-P-P) program in 1965. The program aimed to reach the widest possible audiences by responding to local requests. The NEA was a successful idea reacting to the new interest in the arts, attributed to three factors, one of them being "a new sense of the importance of cities" (Brenson, 2001, 3). “The program's official aims included: increasing awareness of contemporary art; fostering aesthetic enhancement and socially-minded redevelopment of public spaces..." (Knight, 2008). Two years after the establishment of the NEA the Art in Public Places was created as part of the Visual Arts Program of the Endowment. It exists to provide matching grants to support public art.

The environment surrounding the establishment of the National Endowment for the Arts was characterized by a deep-seeded mistrust for any "alternative" lifestyles. The cultural climate in this period was reactionary to the government secrecy and levels of paranoia in the United States during the Cold War era. During the 1950's and 1960's artists maneuvered a very complex role in American society: they were both celebrated for their "otherness" and unique outlook, yet highly persecuted because of the mistrust of their lifestyle (Brenson, 2001). Arguments for and against the establishment of the NEA showed a tension between "aesthetics and ideology," which serves as a point of contention for the organization to this day (Pimlott, 2006). The NEA was an organization that legitimized the role of artists, acknowledging the importance of art to be present in cities.

John F. Kennedy voiced great support for American artists and actively invited artists (visual artists, writers, etc) to be part of important events. Robert Frost was present and a speaker at Kennedy's inauguration. These partnerships supporting the connection between policy makers and art-makers. One point argued was, (for the) "US to be seen as a 'civilized society' is 
dependent on creative activities of its citizens in art" (Brenson, 2001). It was a marker of "civilization" to have a well-established art base in major metropolitan areas.

The contempt for artists in American culture in the 1950's and 60's created an environment of much distrust for the lifestyle arts encouraged, but the establishment of a federal grant from an official government organization validated the American artist! Suspicion and mistrust for artists had been a common, cultural theme in the US since the close of WWII. The establishment of a National government agency providing grants and subsidized funding to support an "alternative" lifestyle. Through the National Endowment for the Arts and the National Arts and Cultural Development Act of 1964 more than $\$ 4$ billion has been awarded to support artistic excellence, creativity, and innovation to benefit individuals and communities today. The NEA functions through partnerships with state art agencies, local lenders, and other federal agencies, and the philanthropic sector. The NEA is advised by the National Council on the Arts on agency policies and programs, making recommendations to the Chairman on applications for grants, funding guidelines and leadership initiatives.

A shift in practice was initiated in 1965 the US government decided to "trust" and believe in artists, more so than ever, and that by 1995 the regulation of the peer panels shifted establishing trust and set up a more stringent set of guidelines. Politics in the US shifting to the Right ensured that the NEA became controversial in the early 1990's as a result of the organization's support of a broader array of artists and art forms (e.g. Robert Mapplethorpe's provocative nude photographs) (Pimlott, 2006). Despite the controversial nature of the NEA, the organization reached full complement of "regional representatives" linking the Arts Endowment and individuals and organizations in different areas of the country and through controversial times attained a well-defined stature as an institution representing American creative aspirations. Factions came about in attempting to represent a volatile art world, but chairmen developed new programming for historically underrepresented groups expanding the scope of the NEA impacting more groups of society. 
Years later grant funding for public art initiatives came about through creative placemaking projects. Projects that implemented change through not planning, but doing, a process to "build connections between artists and the community that last" (Fallon, 2012). Placemaking as a theme works to empower local communities by valuing intangible aspects that make an area unique. "Placemaking is both an overarching idea and a hands-on tool. The NEA established "Our Town" and announced in 2011 the distribution of $\$ 6.5$ million in grant money to 51 projects in 34 states that involved partnerships between art and design organizations and their local governments. Projects chosen to receive grant funding were selected based on their proposed ability to contribute to toward the "livability of communities," transforming them into "lively, beautiful, and sustainable places with the arts at their core" (Fallon, 2012). Another grant titled ArtPlace awards $\$ 11.5$ million to support 34 creative placemaking projects, helping towns and cities thrive by "strategically integrating artists and arts organizations into key local developments in transportation, housing, community development, job creation and more" (Fallon, 2012).

The term "Creative Placemaking" was coined by National Endowment for the Arts' in the report Creative Placemaking Ann Markusen and Anne Gadwa, describing creative placemaking as a situation in which "partners from public, private, non-profit, and community sectors strategically shape the physical and social character of a neighborhood, town, city, or region around arts and cultural activities. Creative placemaking animates public and private spaces, rejuvenates structures and streetscapes, improves local business viability and public safety, and brings diverse people together to celebrate, inspire, and be inspired" (Markusen \& Gadwa, 2010).

These government agencies and policies ensure the installation of public art in communities, making the claim that aesthetic forms are beneficial for the wellbeing of communities. When addressing public art commissioned for public spaces, “...the installation of public art within the urban fabric is inevitably a political exercise" (Sharp et al. 2005). Today sponsorship for public art initiatives is incredibly diverse. Sponsors of public art range from ad-hoc citizens committees 
to nonprofit institutions and agencies of local governments (e.g. Arts Obispo and Santa Barbara County Arts Commission). Santa Barbara County Arts Commission for example, is informed by the County Board of Supervisors, County Chief Executive Officer, and the County Parks Department. It is also informed by the Santa Barbara City Council, City Administrator and the Community Development Department.

Typically the process for securing sponsorship through its installment is multi-staged. First a site is selected and the necessary permissions for its use are acquired. Second a selection panel is organized and they are instructed to choose an artist whose work is appropriate to that site. Third, fundraising and community relations efforts are initiated, a public information program established with clear goals of the project outlined. The community is informed, presenting the reasoning behind the artist's selection and information about their work. A budget is formulated taking into account the scale, nature of the site and the requirements of the artist. The artwork is created, transported, and installed in the public setting. The artwork is dedicated and introduced into public life.

Differing art forms communicate differently. Permanent versus impermanent. Rhetorically different art forms communicate to their surrounding in radically different ways depending on their purpose, materials use, space they are situated in, and level of interactivity. Impermanent works have a different interplay with the culture they are infused in because of their temporality.

Modern public art is typically classified by the Chicago Picasso or Calder's La Grande Vitesse both pieces that went on to embody a City's collective spirit and act as a unifying piece for the community's collective vision of place. 


\section{"New Public Art" of the 1980's- Art \& Function}

Public art in civic city plazas has been criticized for exhibiting pieces that are elegant yet bland. The criticized pieces tend to feature murals that art bright and colorful or unique whimsical sculptures rather than pieces that are thought provoking. These pieces do more to please an audience and avoid controversy than they do to initiate a social-community dialogue. Tom Finklepearl is commended in his book Dialogues in Public Art for putting the "public" back into public art and showing the possibilities for art that is pleasing, engaged in social issues, and having the capacity to instigate change.

Claims of New Public Art include the opposition of cultural elitism and the artist/sponsor to remain committed to artistic quality. Attributes of New Public Art were outlined in many ways to combat tired tropes assigned to public art and the criticism aligned with bland works, and to infuse the art as an integral part of public space within urban centers. "Public art needs to be seen as a function, not of art, but of urbanism. It needs to be thought of in relation to, rather than insulated from the numerous other functions, activities and imperatives that condition the fabric of city life." (Deutsche, 64, 1996).

One trope of "new notion of public art" (Deutsche, 1996) is exemplified in the planning of one of New York City's "greatest public spaces"Battery Park City, New York. Battery Park City is built entirely on landfill on the bank of the Hudson River, but today the vibrant neighborhood boasts nearly thirty-five acres of gardens, parks, plazas and public areas. The redevelopment worked to "redefine

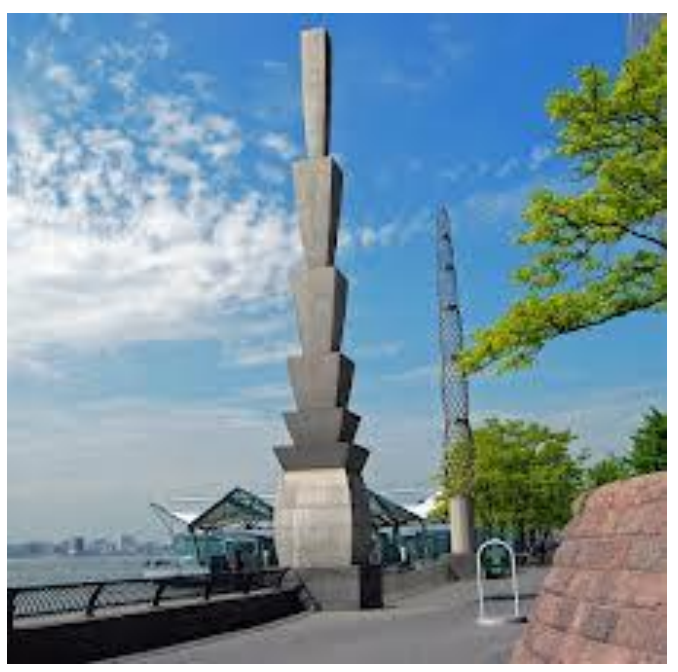

Figure 4: "Pylons", Martin Puryear, 1995. Battery Park City, New York.

the respective roles of architect, art, and landscape designer in the planning of large-scale building projects...the artists are to function... as co- 
designers of the space" (Deutsche,1996, 80) These outlined goals worked to "put the function back into art again" (Deutsche, 1996, 65) so that the use of the artwork ensures relevance to the space, time, place, and surroundings of the artwork. Scott Burton maintains that 'Utility' is the principal yardstick for measuring the value of public art. Therefore, "new art, then, is promoted as useful in the reductive sense of fulfilling supposedly essential human and social needs" (Deutsche, 65). Relating the concepts of "utility" to the ideal of "social good," the marketing of AIPP- government funded art as "community sponsored" is problematic and a test of values and priorities.

Artists also began adopting a performative, process-based approach as "context providers" versus the product (art) as "content providers." Dialogue-based art" is seen as especially impactful as a mode for sparking discussion. Jenny Holzer's work as a conceptual artist exemplified these themes through her 'For the City' works where she transforms the exteriors of public spaces in New York into places of contemplation, reflection, and discussion by projecting declassified documents onto New York University's Bobst Library and poetry onto the exteriors of Rockefeller Center and New York Public Library in Manhattan. The Modernist Movement and Modern Art efforts in the $20^{\text {th }}$ Century notes that while historically patrons have used artworks to promote their political interests, modern artists work independently-minded.

Public Art has been, and continues to be controversial. "Hot words" related to the installation and perception of public art include: provocative, disruptive, and contentious. It is problematic for public spheres, themes surrounding public art are extremely problematic. "Public Art" is described as an oxymoron according to the standards of modernist art and aesthetics theory, focusing on subjective experience. "Art is taken to be the product of an individual and autonomous act of expression, and its appreciation is, likewise a private act of contemplation. By contrast, as a public phenomenon, art must entail the artist's self-negation and deference to a collective community" (Hein, 1996). 
"Publicity has social and political connotations that are untranslatable to public access." "The concept of a "public" has become so problematized that putative works of public art demand justification in terms of qualitatively unrelated analyses of public space, public ownership, public representation, public interest, and the public sphere" (Hein, 1996)... "few works address or embody all of these aspects of publicity, and their selective attention to one or more of them-frequently conflict-ridden — accounts for the baffling variety of items proffered as public art" (Hein, 1996). There are many controversial issues associated with public installations, among those being the discussion of "appropriateness;" whether a piece is considered profane or is a culturally celebrated art form.

\section{Controversies in Public Art and Civic Engagement}

Examples of "failures" or major controversies that led to the questioning of the role of public artwork in social realms impact social reception and exemplify the sensitivity of working with multiple publics. A discussion of inclusion is useful when talking about the "success" of public artworks. Inclusion is achieved when local communities take ownership of artworks, for example, when community members provided guided tours of the artwork installed in their community (Sharp et al., 2005). The notion of civic pride that public art instills serves a factor for tourism bringing people to spaces because they are unique and celebrated for being so.

Charles Laundry writes, "I believe the greatest contribution artists can make to city making is in the way they think, rather than any specific piece of public art, however good, they produce" (Landry, 2012). Public art is fundamentally problematic when discussed in relation to the footings of planned city structure. "Involvement with the artistic can create problems for typical urban managers because the values and attributes that dominate the modern world are almost diametrically opposed to the values promoted by artistic creativity" (Landry, 2012). Landry maintains that the worldview of city managers value certainty and predictability, characterized by strategy- planning, hard, measurable calculations, etc. Where artists and "artistic creativity 
involves a journey, a quest for the profound, having no calculated purpose, accepting of ambiguity, uncertainty, and paradox" (Landry, 2012). "Good art is (also) transgressive and disruptive of the existing order, and it is often uncomfortable. Again, these are attributes that urban decision makers can find worrying" (Landry, 2012).

Landry outlines what he calls the "six threads of "civic urbanity"" as explanatory of urban virtues that encourage connectivity between public art and urbanity. The six threads being: First, the idea of the intercultural city, acknowledging that great cities thrive on "good diversity, and artistic initiatives encourage crossing the divides." Second, fostering eco-consciousness, as forward movement with eco-intentions require new aesthetic for buildings to foster behavioral change. Third, practical urban planning focused on community health, valuing walkable city design giving people the time and space to experience the city in a visceral way. Fourth is the demand for shared commons, spaces that are free and noncommercial. Fifth, the aesthetic imperative reminds us that that every physical structure has an aesthetic responsibility its environment. Lastly, the notion of creative city making, as a form of planning places that encourages imagination and inventiveness in solving urban problems and grasping opportunities (Landry, 2012). 
Richard Serra's "Tilted Arc”

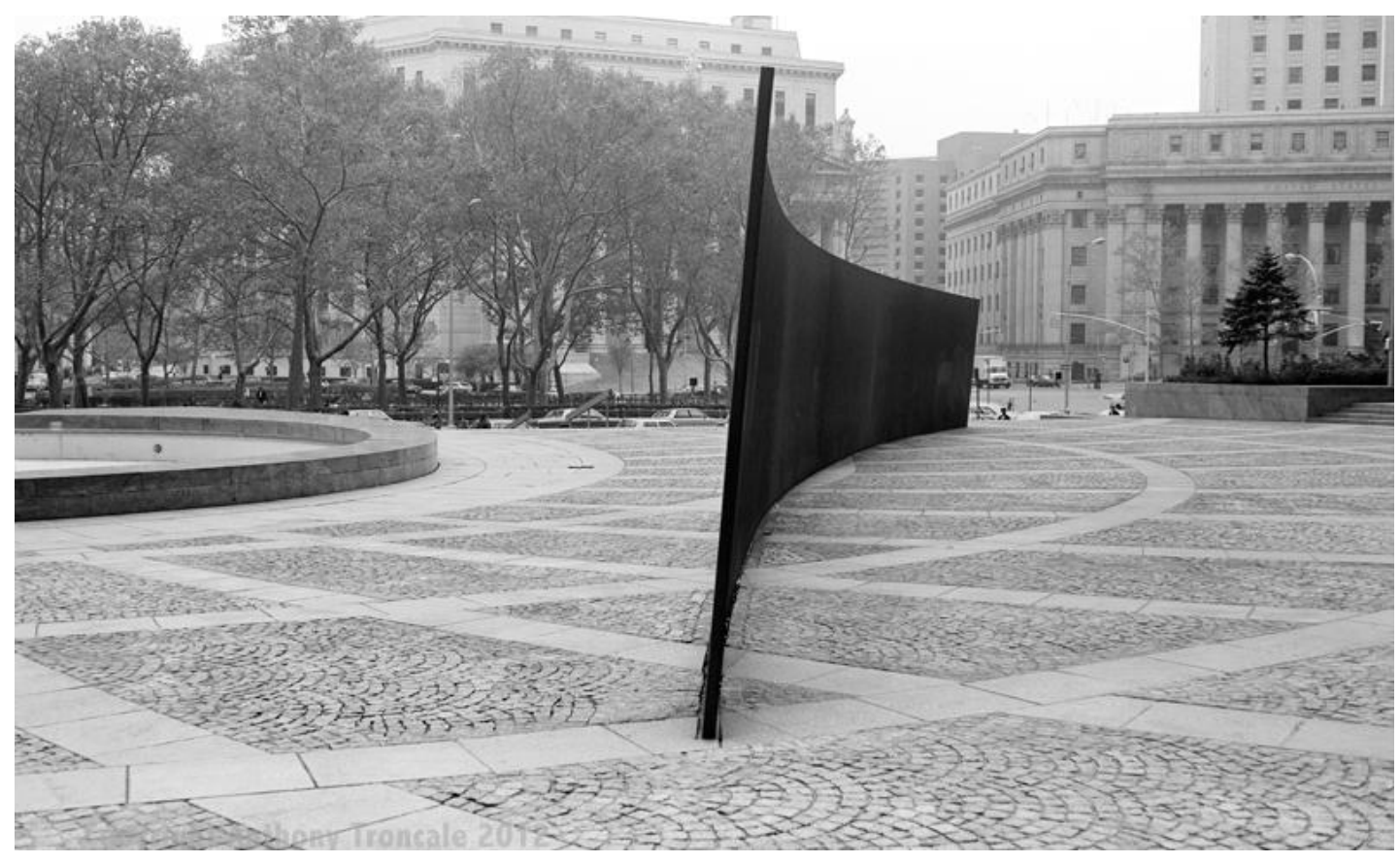

Figure 5: "Tilted Arc", 1981 Richard Serra.

Federal Plaza, Manhattan, New York.

Richard Serra created the piece Tilted Arc in 1981, causing great controversy within its

community leading to its removal from Federal Plaza in Manhattan. Serra saw his sculpture as "challenging the bourgeois bureaucratic spaces that usually contextualize the display of artwork."

The sculpture was designed to critique the alienating square, which the public appreciated, but did not support the aesthetic form he used- a $120 \mathrm{ft}$ long wall, 12 feet tall that bisected the square.

One worker responded to the sculpture, "I do not care to be challenged on a daily basis by something designed to be hostile" and another observer concluded that "What we need... is something to enliven our lives, not something which reinforces the negativity of our work lives" (Sharp et al., 2005). The General Services Administration (GSA), the same agency that facilitated its installment, removed the piece eight years after it was installed.

Serra meant for Tilted Arc to "confront the public in behavior space "in which the viewer interacts with the sculpture in its context... to engage the public in a dialogue that would enhance, both perceptually and conceptually, its relation to the entire plaza.... He hoped that the sculpture 
would redefine the space in terms of itself..." (Hein, 3). For Serra the work was a critique of the way public space is designed. An artists will sit at the crux of community desires and personal expression. Navigating this political process while creating a meaningful piece can be a challenge.

\section{"The Tacoma Dome Neons"}

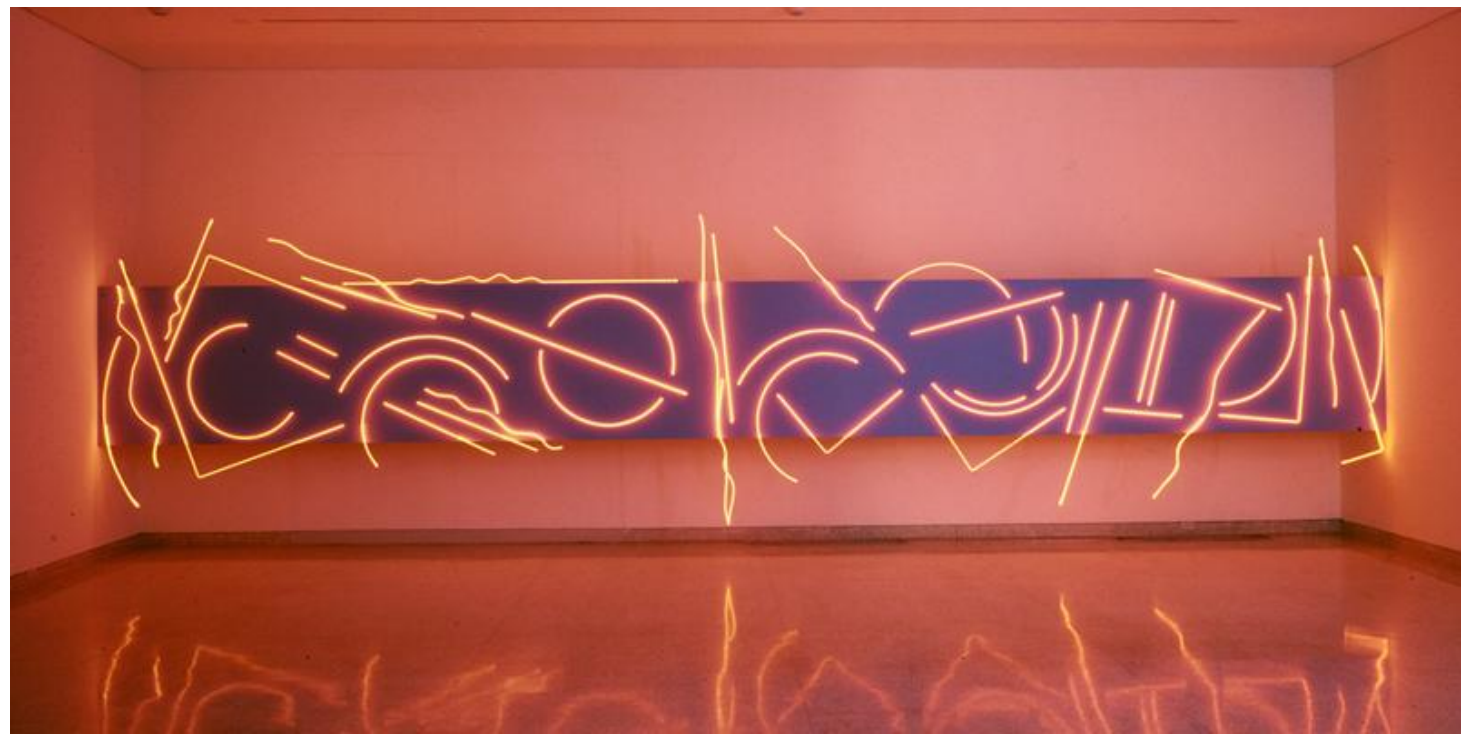

Figure 6: Neon for La Jolla, Stephen Anotonakos, 1984

In the early 1980's Tacoma set in motion a nationwide Request for Proposal, inviting artists to submit proposals for a public artwork to be installed at the newly constructed Tacoma Dome sports and convention facility. The search produced proposals from influential and widely known American artists, including Andy Warhol, that were then to be evaluated for appropriateness for the community and then a vote was taken by the Tacoma public. In 1984 the Tacoma city council voted to accept the proposal of New York artist Stephen Antonakos's set of abstract neon sculptures. The $\$ 280,000$ neon sculptures were paid for by funds from the city's new Percent-for Art funding. Seven months after the installation of the Tacoma Dome Neons the Tacoma public voted by a three-to-one margin to remove the sculptures. The public had found the sculptures to be "inappropriate and a waste of public moneys" (Kates \& O'Hare, 1987). The case was broadcasted in the video "Tacoma Neon Wars." The film shows cable television coverage of 
the dispute, showing public hearings from before and after the sculpture was installed and the Dome Art Dedication Ceremony. Because of the huge outcry the statues were removed. From 1980 to 1985 Tacoma had a legally binding Percent for Art

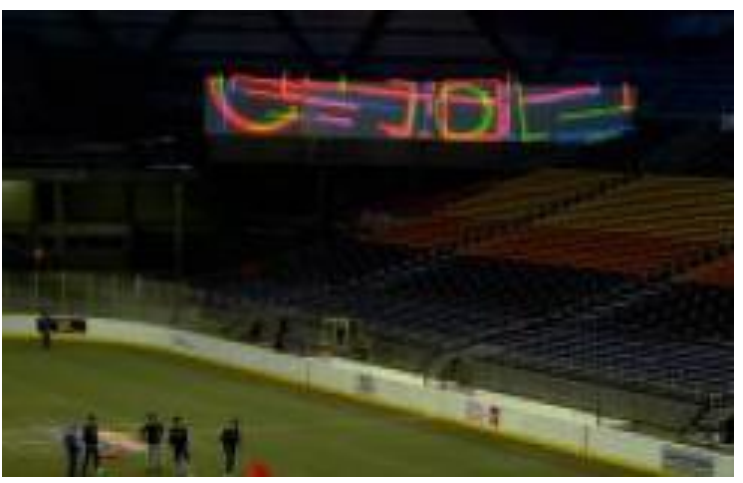
ordinance that required the city to spend a percentage of every public construction dollar for public art works. After the Figure 7: Neons for the Tacoma Dome, Stephen Antonakos, 1980, Tacoma, Washington (prior to removal).

lengthy public debate over the Tacoma Dome Neons, the Percent for Art ordinance was repealed in the following general election. (McLennan,1994). The Percent for Art funding was not brought back to Tacoma until 2000, and this time with restrictions. I will now refer to Stephen Antonakos's pieces and the controversy surrounding them as the Tacoma Dome neon debate. The neon debate colored Tacoma's cultural climate surrounding public artwork for roughly fifteen years. The term "public artwork" was deemed a dirty word. Large public artworks, like the Museum of Glass and the Glass Bridge that were widely supported by Tacoma's public were privately funded. It is important to reflect on why such a democratic process produced a piece that was incredibly unsuccessful for the community who selected it. What should be the center of discussion to ensure that another very involved public selection process does not produce a piece that does not meet the needs of the community? 
"Much Ado About W: Art Wars on State Street" in Santa Barbara, CA

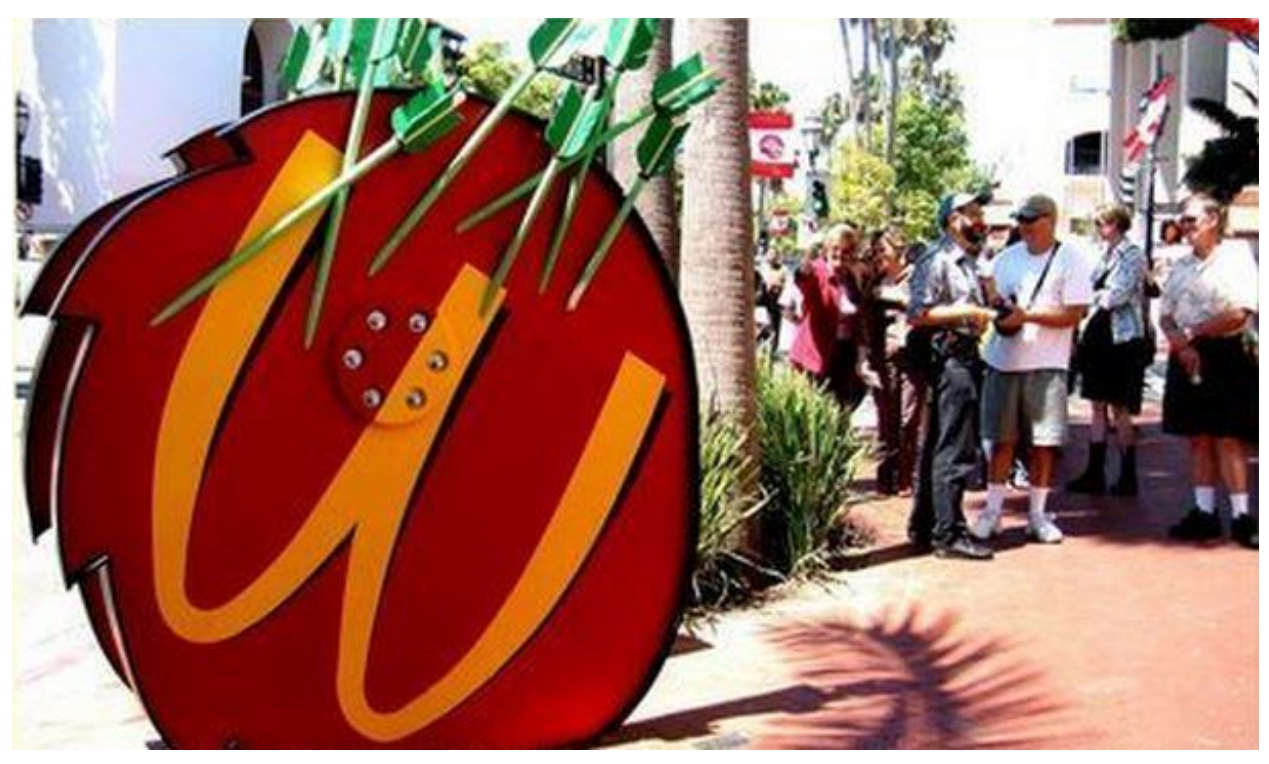

Figure 8: "W", Colin Gray, 2006, Santa Barbara, California

The notion that art forms should be controversial is a tenant agreed upon by many artists for making successful and meaningful art. Artist Colin Gray created a public sculpture displayed on State Street in downtown Santa Barbara, California. In 2006, Gray's sculpture "W" which featured an upside down McDonald's logo shot full of green arrows, sat at the intersection of State Street and Canon Perdido. Fierce opposition to the piece was led by the owner of six Santa Barbara local McDonald's franchises and son of the Egg McMuffin inventor. The opposition's mission was to have the piece removed with arguments citing the sculpture to be "mean spirited." The controversy surrounding the public installment spurred threats and tabloid journalism aimed at attacking the Santa Barbara County Arts Commission. The documentary film, Much Ado About W: Art Wars of Santa Barbara chronicles the heated debate. Discussions were brought back to the Santa Barbara County Arts Commission asking questions of "appropriateness" and whether logos should be prohibited from future public art. In the documentary artist Colin Gray quotes Ram Dass: "'When we get to that point where we give up all notions of what it is to be good in order to be free, with the faith that when we are free, we will be good.' And that is a beautiful succinct 
thing for making art too" (Love \& Love, 2007). The fact that this piece was temporary meant that the City's arts organization could have a bit more flexibility in terms of what they could encourage and have on the street (for a short period of time). The temporality of the piece allowed for it to be placed downtown in a highly visible place and then be removed after the installation. In many ways this piece is very successful in accomplishing many of the feats public art can put forth in a community. It caused discussion, negative may be it, but people were active in articulating what they did not like and why!

\section{Current Examples in Public Art}

\section{New Functions of Public Art}

Public art is now celebrated in a myriad of forms that transform city streetscapes into interactive spaces inviting dialogue between multiple publics using the common space. Empty storefronts as a result of the economic downturn have provided an especially interesting potential for public art works. These once empty store fronts are decorated with temporary public arts works- this opportunity for artistic presentation keep central business districts varied, attracting people to spend time and money in the area. Collective Street Art projects to the likes of the Tacoma Graffitti Garages and "Tour Paris 13" are becoming popular tourist destinations that engage visitors in grappling with themes of impermanence in the heart of a structure that is either condemned or in disrepair. The following examples shows a great variety of public art projects and the impact that they have on the surrounding community.

Spaceworks Tacoma, of Tacoma, WA, is an organization that works as a joint initiative of the City of Tacoma and the Tacoma-Pierce County Chamber of Commerce. Spaceworks Tacoma is designed to "activate empty storefronts and vacant spaces in Tacoma, WA with art and creative enterprise. Property owners donate their vacant spaces and program participants transform them into dynamic points of interest with site-specific installations, called Artscapes, to host artist and 
special projects residences, creative retail and pop-up events. Spaceworks initiatives reflects Henri Lefebvre's theory of rhythm binding urbanity together. With the goal and mission of reviving vacant storefronts with works of art, the rhythm or pulse that is ever present in cities maintains strength.

The initiative makes no- and low-cost temporary space, training, and technical assistance available to artists, creative entrepreneurs, organizations, and community groups in order to nurture successful projects that transform Tacoma into a stronger, more active city. The organization now partners with Tacoma-Pierce County Chamber, Tacoma Arts Commission, the Greater Tacoma Community Foundation, Art Works, Americans for the Arts, and Ovation-Art Everywhere.

Tacoma's annual Art at Work Month is the celebration of various artists in the City of Tacoma, WA working in cooperation with multiple organizations and local government groups. The annual event is sponsored and made possible by the Tacoma Arts Commission. In 2013 Tacoma celebrated their $12^{\text {th }}$ annual Art at Work Month including music by Taxi Driver, molten iron pour by Tacoma Community College, contemporary dance $\mathrm{b}$ the BareFoot Collective, urban arts by Fab-5, poetry by Tacoma Poet Laureate Lucas Smiraldo, films by local filmmakers, collaboration efforts for a new public art piece, "The Locks.” Celebrations also include the AMOCAT Arts Awards, presented by the City's mayor. 
October 2013 marks the third annual installation of the "Pianos on State," a collaborative musical experiment project in downtown Santa Barbara, CA. The project features a dozen or so pianos that have been painted and embellished by local artists and then are displayed in various locations

around downtown Santa Barbara with an invitation for community members to take a

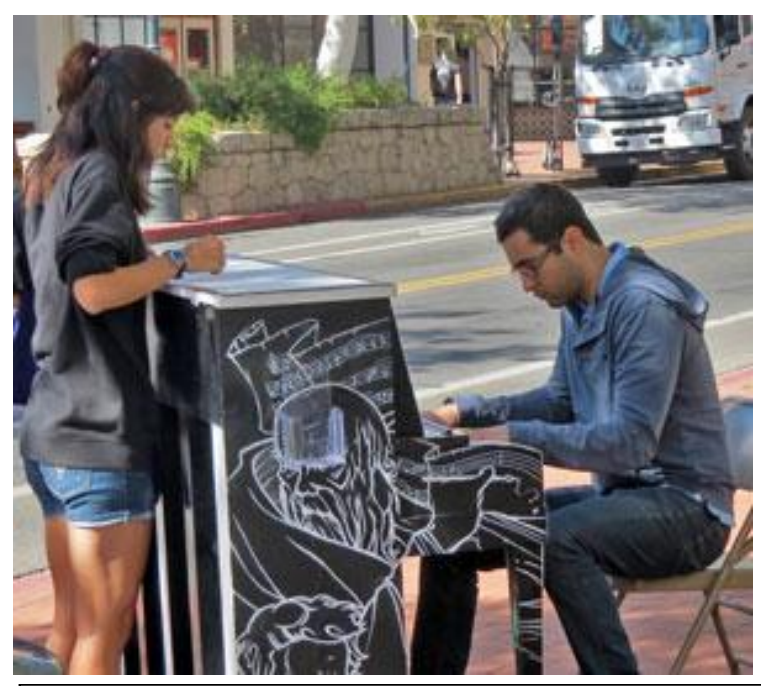

Figure 9: Pianos on State Street, collaboration of artists, 2013, Santa Barbara, CA

moment and express themselves in a very public, outdoor arena. The pianos are available for playing between 9am and 9pm. The Santa Barbara project was inspired by other artistic communities in Denver, Colorado, Lancaster, Pennsylvania, and New York, NY. "We're all about making arts accessible to the public," said Ginny Brush, executive director of the Santa Barbara County Arts Commission, a lead organizer. "It's definitely one of those 'It takes a village' kind of projects."

The Riverside Art Museum (RAM) project is a series of public art happenings throughout the city of Riverside. The project is funded by the James Irvine Foundation and the City of Riverside Arts and Culture Grant. The project entails neighborhoods hosting "art happenings" where artworks will be created. The artwork created will be displayed at a non-traditional public art venue (such as a repurposed shipping container located in an area with high foot traffic). RAM encourages local partnerships and community involvement in transforming untraditional spaces into spaces acknowledged for their artistic opportunities. 
Public Art took an

active form in Paris in 2013.

"Tour Paris 13" is billed as

the biggest-ever collective

street art exhibition. Fall 2013

a condemned apartment tower

in Paris was turned over to

105 international street artists.

This opportunity gave each

artist the chance to turn each

home into its own art

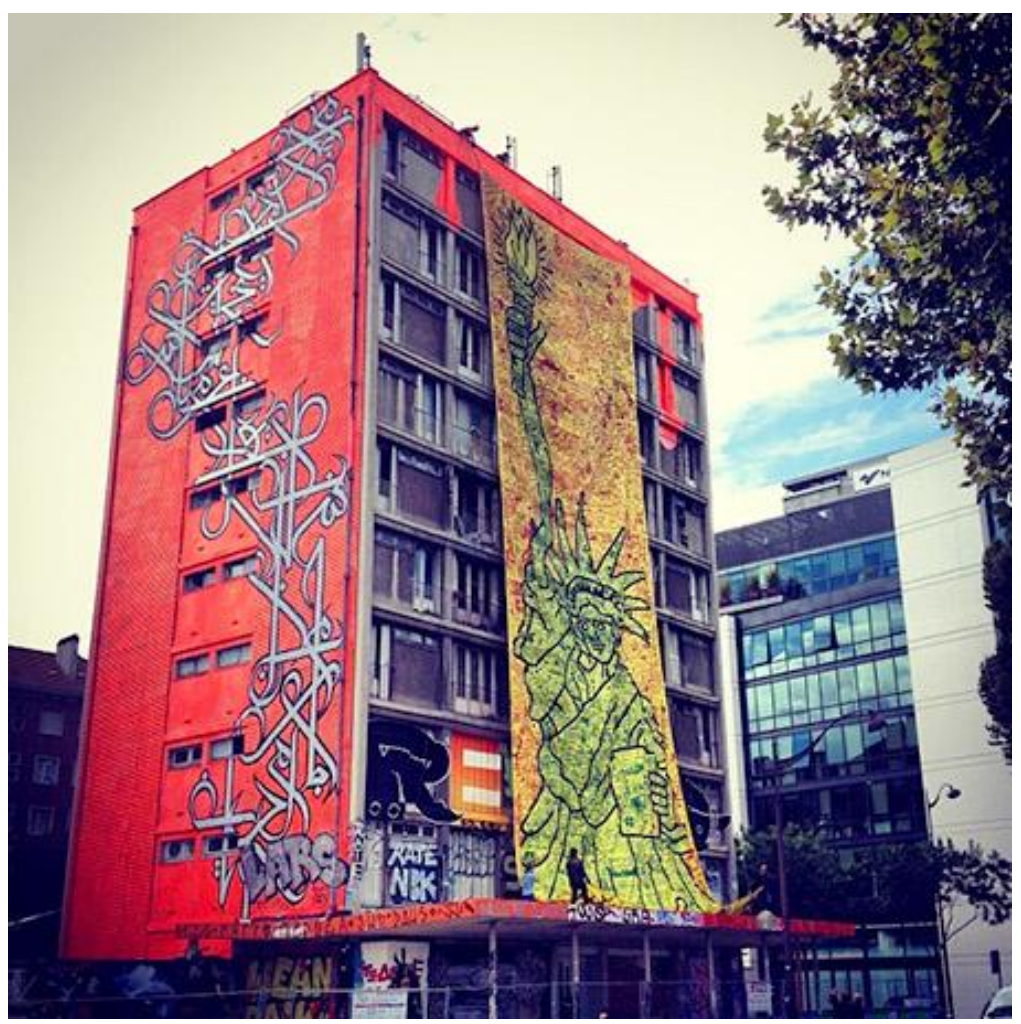

installation during the building's final days. This

form of artistic activism is particularly unique in

Figure 10: "Tour Paris 13”, collaboration of artists, 2013. Paris, France

the transformation of personal living units into public spaces for artistic consumption. These are temporary installations as all the artworks will disappear by the end of the ear as the building is demolished. "I really wanted the artist to intervene on a whole space," said Mehdi Ben Cheikh, the gallery owner who initiated the project. "I didn't want the spectators to come and look at the art. I wanted the spectator to come and enter an art work... which means there are things everywhere- we enter a room, and have to turn in every direction to understand the surroundings." The collaborative spirit of the exhibit was inspiring to artists and those thinking about how to transform places that had fallen into disrepair. The project was incredibly unique in so many ways, but the temporality of the exhibit meant that more liberties could be taken and that people had to act now if they wanted to see the incredible collaboration project.

Los Angeles artist Mear One beamed that street art has presence here and now! (Referring to graffiti art as the world's biggest art movement) "In the 1970's, art was so elite that 
only the upper level people could do art or appreciate. So it got boring... and now, we are in a situation where this is the art form." In association with this event an International urban contemporary art auction took place on October 25, 2013 that featured works of street artists alongside works of world-renowned, established artists Keith Haring and Basquiat. A highly esteemed art auction in Paris was created for the purpose of celebrating and hailing "alternative artists" and street art as fine art and a recognized art form! A similar project took place in Oakland, CA imparting the social implications of celebrating an art type that had been historically scorned and deemed to be dirty and below "fine art."

An example of where public art works raises awareness is exemplified in the case of a neighborhood project in Santo Antộnio, Brazil where a creative community art project was created carried out between November 2010 and July 2011 to answer the pertinent question: Where does the water we drink come from? The project was called the "Street Water Project" and the activities consisted of art and environment workshops in schools and poetic interventions in public spaces designed to raise awareness of the population regarding the water sources that supply the city.

Public art can act as a form of activism; a mode for attaining public response as exemplified by Candy Chang' "installations" in New Orleans, Alaska, Sweden, etc. Her works make a connection between Public, Visual Art and City Planning. Candy Chang's interdisciplinary approach works to combine the fields of urban planning, street art and graphic design. She is an artist, designer, and urban planner from New Orleans who has created public art projects in New Orleans, Hong Kong, Las Vegas, and New York City, and her work has been exhibited in the Venice Biennale, the Smithsonian Cooper-Hewitt National Design Museum, the Centre for the Living Arts, and the Southbank Centre. Her work identifies questions of the limitations residents have in communicating with their entire community. Her questions turned into experiments in 
public space. She creates interactive public art projects to share housing costs, resources, memories, and hopes for abandoned buildings.

Chang's work impacts shared public spaces. Her projects utilize inexpensive tools of stickers, stencils, and chalk to create works of "art" that serve a purpose in gathering community input, articulating community sentiments, and presenting goals for which the community can grow. The works use shared memories to gain better understanding of our landscapes, the way individuals interact in urban settings, and how they should look in the future.

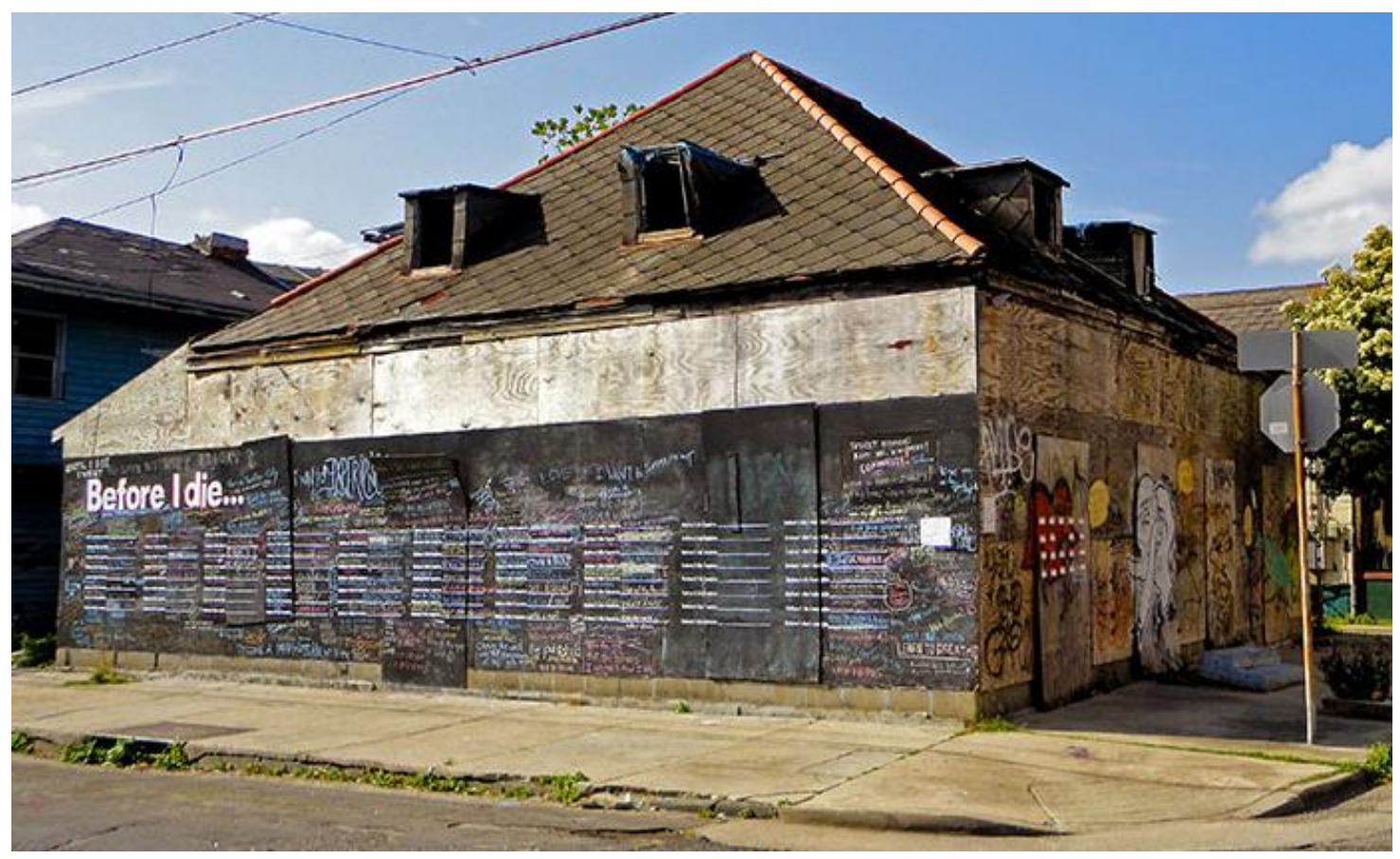

Figure 11: "Before I Die”, Candy Chang, 2011. New Orleans, Louisiana.

Chang's most famous and recreated work, "Before I die" gives the opportunity for a community to document personal aspirations (e.g straddle the international dateline, live off the grid, be someone's cavalry). Chang developed "Before I Die toolkits” for public purchase, allowing local groups to discover how powerful our public spaces can be in capturing the memories, dreams, and wishes of those inhabiting or visiting the community. 
Her roots in New Orleans bring together beautiful architecture after Hurricane Katrina the highest rate of abandoned buildings. Her innovative thinking creates artwork that is both a community collaboration and an effective way of gathering public input that is both meaningful to a planning department and empowering to the community residents that contributed to it. Chang's project "I Wish This

Was," conducted in New

Orleans in 2010, provided on-site civic input for what community members wished

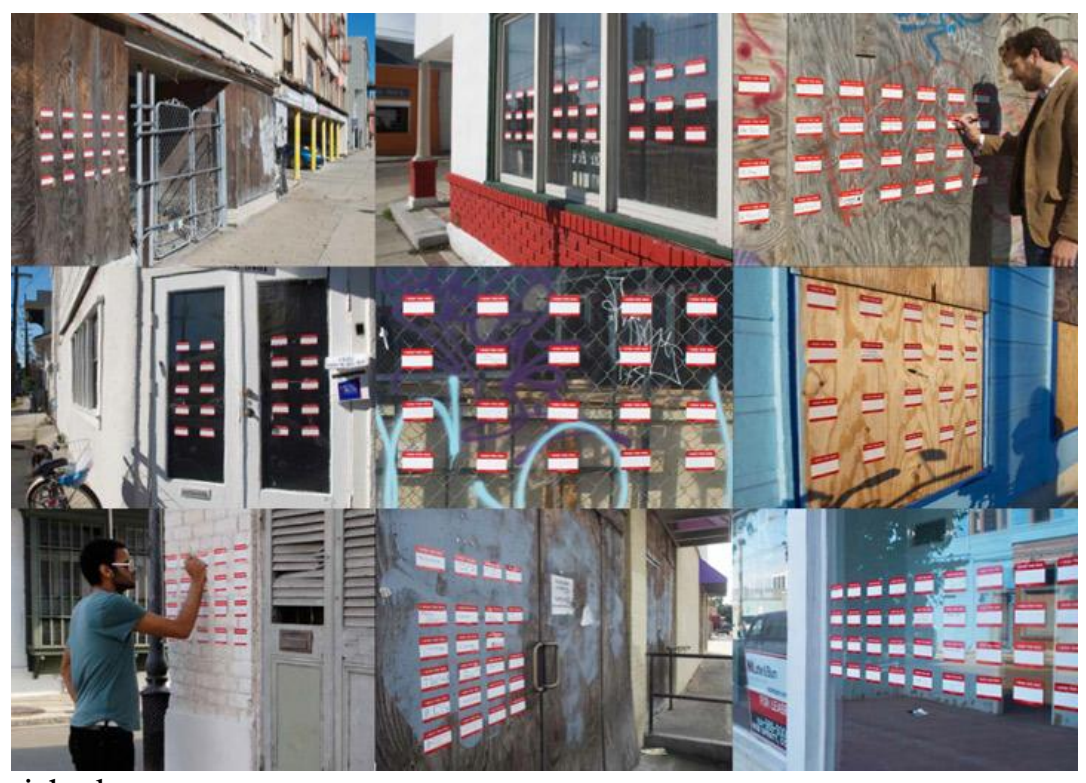
Figures 12 \& 13: "I Wish This Was", Candy Chang, 2010. New Orleans, Louisiana.

empty store fronts would be in their community. The project essentially takes City Hall to the streets and asks community members to comment on what land uses are appropriate for a space. For this project a neglected space becomes a

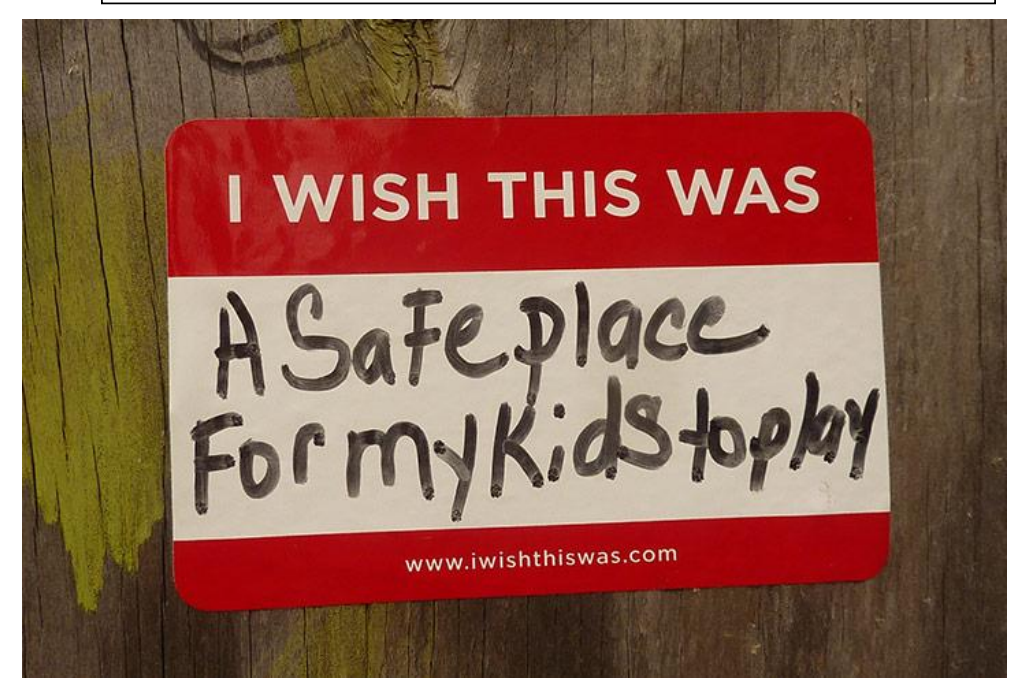
constructive one!

She maintains that understanding our neighbors and making space for reflection and contemplation are humanizers and is the way to create good, useful people spaces. When analyzing public artworks like Chang's it is important to maintain perspective! Life is 
impermanent and meant to be celebrated. She maintains that it is useful to think about death and life and the ever constant urban spaces that will outlive us and be the backdrop for generations to come. The combination of art endeavors and planning initiatives remind that the traditional mode of collecting community input for future development and that the projects Chang has created can transcend and surpass what traditional planning and town hall meetings should look like. These projects are meaningful ways to share hopes, fears and stories that impact how an individual is part of the City they inhabit.

Chang is the co-founder of Neighborland.com (working with National Partner ARTPLACE), a group working to give community meaning and clot to the theme: "Good ideas for Cities." The Civic engagement process utilizes a web-based platform to generate ideas and facilitate discussions within the community on how to better the space around them. Neighborland works to create strong ties in communities.

\section{Art Initiatives}

The following art initiatives and groups of artists provide examples for the ways in which art (events, installations, etc) can now be integrated into the social, urban settings, within a complex urban landscape. They are initiatives that expand the ways in which art reaches the publics they work in.

At the local level, Arts Obispo is a County-serving arts organization working in collaboration with the San Luis Obispo County Arts Council and the local partner of the California Art Council to advance the visual, literary and performing arts through programs that promote public access to the arts, arts in educational settings, local arts planning and collaboration, and opportunities for artists and arts organizations. Arts Obsispo initiated the following programs active in San Luis Obispo: 
Art After Dark- Every first Friday of the month dozens of galleries and non-traditional exhibit spaces in downtown San Luis Obispo open their doors in a free event to exhibit the works of local artists. The myriad of art forms exhibited range from painting to sculpture to musical performance, etc. The events are wildly popular and work to form partnerships between SLO Chamber of Commerce, local businesses, and artists. There is also an Art After Dark monthly event in Paso Robles held the first Saturday of each month.

The Arts in Education program works to empower youth through multiple opportunities to experience and participate in the arts in San Luis Obispo County. Arts in Education sponsors multiple events/ programs including: Poetry Out Loud, Passport to the Arts, Arts Curriculum Assistance, and the California State Summer School for the Arts.

Art in Public Places (APP) Coalition helps implement countywide policies for public artwork, spreading the message of advocating for art in public places, both public and private, for the cultural enrichment of San Luis Obispo County, including cities and unincorporated areas. The group has worked behind the scenes assisting with the installations in the new County Government Center in Avila Beach, SLO Promenade, Old Town Arroyo Grande, Higuera St. Plaza and the Tolosa Housing Development.

The Artists Opportunities blog shows postings for calls for art/artists in San Luis Obispo County, providing to be a place for artists to be notified of opportunities for them to offer their skills and for developers and others initiating arts projects to get in contact with local artists.

SLO County Arts Talk Sessions (SLOCATS) is an opportunity to build community between administrators, directors, board members, artists, activists, community leaders, and others interested in arts happenings. The monthly event provides the opportunity to exchange information, strategize, collaborate, and advocate for art, encouraging communication between various participants. 
The organizational structure of Arts Obispo allows for multiple programs to be in place to serve all of San Luis Obispo County.

In Tucson, Arizona, JB Public Art, headed by Artists Blessing Hancock \& Joe O'Connell, is a partnership of interdisciplinary workers: artists, metal workers, engineers, and planning initiatives works to liven the streets of their desert community. The artists are world-renowned for their international Public art exhibits, and are community heroes for the work they produced for Tucson, AZ. The collective operates out of Creative Machines Inc, a fabrication facility in Tucson, AZ, working with 14 artists, designers, engineers and craftspeople. Together the initiative has mastered a wide range of media: fabricated metal, acrylic, landscape architecture, LED lighting, kinetic sculpture and electronics. They note, "Our goal has always been to find new ways to live with art - ways in which art solves problems, enriches the human experience and creates an atmosphere of participation, curiosity, and connection to community. We strive to make art that is iconic from a distance yet nuanced up close and have found that this type of work sustains engagement and encourages community interaction" (O'Connell \& Hancock, 2013).

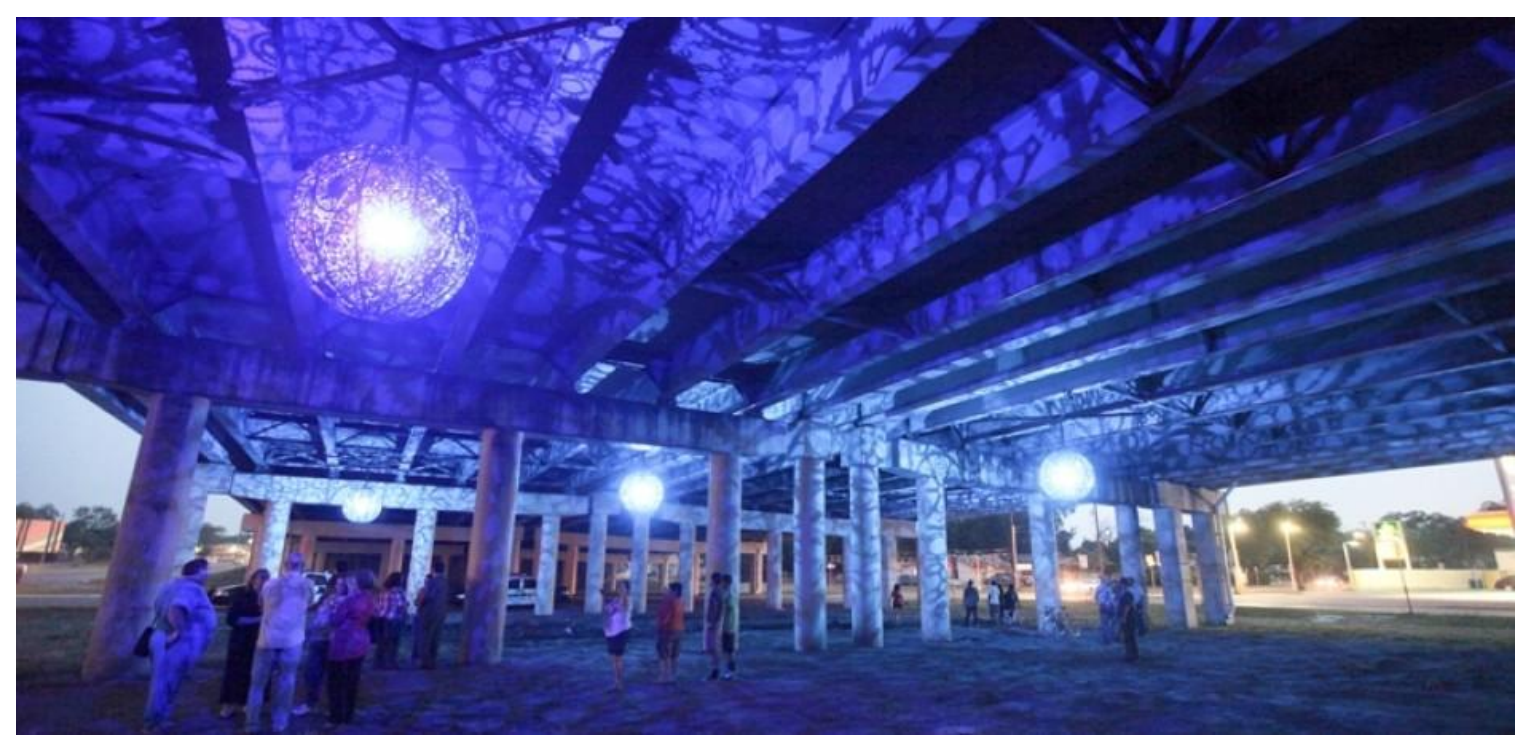

In San Antonio, TX the group installed a series six of light fixtures in a

Figure 14: "Ballroom Luminoso," Joe O'Connell \& Blessing Hancock, 2013, San Antonio, TX. 
blighted area under an underpass for IH 35, creating a zone that is now safe having been beautified by a light installation. The piece, titled "Ballroom Luminoso" is made of 6 colorchanging chandeliers constructed out of recycled bicycle parts, steel and custom LED fixtures. The piece transforms a forgotten, neglected place into one that connects the community. The piece references the area's past, present, and future, featuring intricately designed medallions that draw on the community's agricultural history and strong Hispanic heritage. The piece was featured in Atlantic Cities, Installation Magazine, the San Antonio Current, and Vogelvrije for the piece's ability to meld grandeur with a neighborhood rejuvenation project taking recycled bike parts and turning them into refined forms. The ability for an art piece to create zones for social interactions, in transforming blighted or unused areas into safe and celebrated spaces accomplishes a number of goals, of those adding additional opportunities for art and effectively making a safe space. The opportunities for planners to work together is huge to accomplish many goals.

Culture NOW is a non-profit organization, bringing public artworks to multiple publics through their programming for cultural mapping, cultural tourism, educational enhancement, and planning. CultureNOW, established in 2002dedicates itself to celebrating our vast cultural environment as a gallery that exists beyond museum walls through cultural tourism and arts education. CultureNOW believes that the three facets to understanding the world around us are art, architecture and history. Mapping these empowers the public to better visualize the place they live in making it a powerful tool to understand the richness and diversity of a community.

CultureNOW is powered by a network of professionals - scholars, artists, architects, urban planners, educators, curators, historians - who generously volunteer their time and expertise to advance our mission. Currently, over 75 public art collections across America are collaborating with cultureNOW to create a digital National Gallery of art and architecture in the public realm, in other words a "Museum Without Walls." 


\section{CHAPTER III. Methodology}

\section{Research Question}

There are three main role players in the discussion of public art: the local government, the artist, and the public. Are there differences in their expectations and how they are prioritized regarding public art? If yes, then what are the implications for developing public art policy for varied publics? How is the public policy established in San Luis Obispo efficient in achieving the goals of the main role players, and what if any are the areas where there is a gap in information or ideology? What can be done to close that gap?

\section{Research Design}

In this study a combination of research methods to are used to gather data to provide context: in-depth, expert interviews, participant observation, and creative surveying. The following section outlines explanation building with framework of content analysis of qualitative data gathered through the following methods:

Expert interviews of key role players who inform the decision-making process for the public installation of artwork, intentions and priorities will be highlighted. The interviews will outline expectations of the "role players," their role in the process for installing public artwork in San Luis Obispo, and the prioritization of their expectations. Asking about their position within the municipal public art planning process and what are their expectations for public art?

The research includes three in-depth interviews of representatives from Arts Obispo County arts organization, the Public Art Program Director in the Parks and Recreation Department, and Senior Planner in the Community Development Department to understand the partnerships that allow for the success of artwork installations, festivals, events and artistic initiatives. Expert interviews along with public surveying inform the research on what is commonly understood about the process and what is misconstrued. The public outreach surveying took place at the 
monthly Art After Dark event in downtown San Luis Obispo and was heavily influenced by the work of artist/planner Candy Chang.

Creative surveying took form in a public participation activity with interactive posting boards situated on Higuera Street outside Art After Dark event locations asking participants to fill out stickers with the following prompts: "I think public art...," "I see public art....," "I want public art..." These stickers were be put on boards in and outside the "galleries," so that they can initiate a community-wide discussion. These posters attracted people to the event spaces and facilitated a community discussion about how they feel about public art, what it should do, and how public art should manifest in the future.

The research outlines the municipal process of installing public artwork by studying the San Luis Obispo Public Art Policies \& Procedures Manual. The process is then compared to three major role players' experience of working in the process through expert interviews. These interviews ranging from a half-an-hour to an hour-and-a-half covered a myriad of topics of what they found to be "successful" public art initiatives and where they hoped the future of public art projects would go. This information regarding the municipal process was then compared with how the public (visiting the monthly Arts Obispo Art After Dark Event) viewed public art, what it does, and the role it fits in their community. After reviewing this research the Conclusions Section and give recommendations on how to make the process more user-friendly and better understood by the general public. 


\section{CHAPTER IV. Findings}

\section{Government \& Art: Processes \& Expectations}

The following sections outline the public art installation process in San Luis Obispo, provides a discussion on the limitations and constraints for public art installations, and details surveying gathered during Arts Obispo's monthly Art After Dark event. The process is outlined through the San Luis Obispo Public Art Policies and Procedures Manual prepared by the Parks and Recreation Department for the City of San Luis Obispo. Three expert interviews were conducted with the Director of Arts Obispo (the County arts organization), the Public Art Program Manager (in the Parks and Recreation Department), and Senior Planner Pam Ricci (in the Community Development Department). The interviews provide views of what the process looks like to different administrators at different stages of the process. The surveying activity aimed to gather public option about how public art is perceived and experienced with the San Luis Obispo public. The goal of conducting this surveying was to identify the differences in ideology between how art is planned for in cities and how the public actually function. By identifying these differences a clear distinction can be made between the civic process of prioritizing art projects and what the public would like to see. Several "themes" were identified to categorize the responses to the questions "I think public art...", "I see public art...", and "I want public art...". Themes include public art as it impacts notions of "community," as a mode of expression, articulating emotional responses, what public art does as an "action," public art as a discussion, and locations for public art. This section aims to juxtapose the City-established process for initiating public art works and perceptions of how it acts and what it actually is, outlining potential gaps in understanding between civic process and public impressions. 


\section{The Public Art Installation Process in San Luis Obispo, CA}

\section{The Public Art Policies \& Procedures Manual}

The City of San Luis Obispo employs a public arts program outlined in the San Luis Obispo Public Art Policies \& Procedures Manual. The policy encourages the creation and placement of public art throughout the community. Public art that is developed from the engagement of an artist with public space. The introduction to the Manual sets the stage for the process articulating the complex relationships at play when installing artwork in public spaces. The Manual defines public art not by what it is, but rather describing what public art is not, citing projects (such as “off-the-shelf” benches or fountains, standard landscaping, tiling, or paving) or pre-fabricated installations which do not involve original, creative work by an individual or group are NOT considered as public art. The distinction between architectural ornamentation and art is not always clear making the city's public art guidelines crucial and the review process necessary.

San Luis Obispo is unique with the City's public art program being managed under the Parks and Recreation Department, which in many other cities it is typical to be under administration in the City Manager's office. Parks and Recreation oversees the City's “vibrant” Public Art Program which consists of three distinct components:

The Visual Arts in in Public Places Program: The City of San Luis Obispo administers a Visual Arts in Public Places program which encourages public art in new and existing buildings, parks, streets, and other development projects for the enjoyment of its citizens and visitors. To cover capital projects, the City sets aside one percent (1\%) of the construction cost to a city-wide fund used to support other "worthwhile" public art projects. 
Public Art in Private Development: The City has an ordinance in place requiring the placement of public art, valued at one-half $(.5 \%)$ of the total construction cost, on privately funded, non-residential construction projects costing in excess of $\$ 100,000$.

Private Donations of Public Art: An additional and important source of public art is privately funded and located in a public place. The City has been the recipient of several excellent pieces obtained through the private donation program.

The process for installing public art in municipalities takes three forms: 1.) A developer decides to include artwork in the construction of a new planned development. 2.) Instead of providing public art as part of the construction, a developer pays an in-lieu fee to the City Funded Public Art fund. 3.) An art piece is privately donated to the City to benefit the public. The former is the typical format for public art to function in Cities, but this is highly dependent on whether a City has a Master Plan for Art, a community plan or any established guidelines for installing public artwork at all.

The Following organizational charts outline the funding options for public art. Each type of project whether it be City-funded, privately funded, public art in a private development, or matching grants for public art requires a specific process, all types follow a similar process of proposal submittal, jury review, approval by the necessary review committees, and installation.

To help navigate the process included is a Glossary of Players and Terms:

- CIP Review Committee- Capital Improvements Plan Committee (comprised of City staff) will recommend a project for public art based on available funding and suitability of project. Committee also recommends funding levels for each project.

- RFP- Request for Proposal

- RFQ- Request for Qualification 
- Jury- Jury is appointed by the Public Art Manager. Public Works or Community Development Department public art team, local artists, Arts Obispo, and neighbors serve as members on Jury. Jury is different each time. Juries are tailored to a particular project/piece.

- ARC-Architectural Review Commission approves artwork and forwards recommendation to City Council for review.

- PRC- Parks and Recreation Committee and/or the Mass Transportation Committee, as appropriate

- CHC-Cultural Heritage Committee

- City Council- approves artwork.

- Public Art Manager- Prepares public art contract. After installation Public Art Manager inspects the artwork and compiles the maintenance information.

Options for the funding for public art includes: city funded public art, privately funded art in public places, public art in private development \& matching grants for public art as outlined in the Public Art Policies \& Procedures Manual. 
1. City Funded Public Art: Each year the City of San Luis Obispo sets aside one percent (1\%) of the estimated cost of eligible projects in its Capital Improvement Plan for public art.

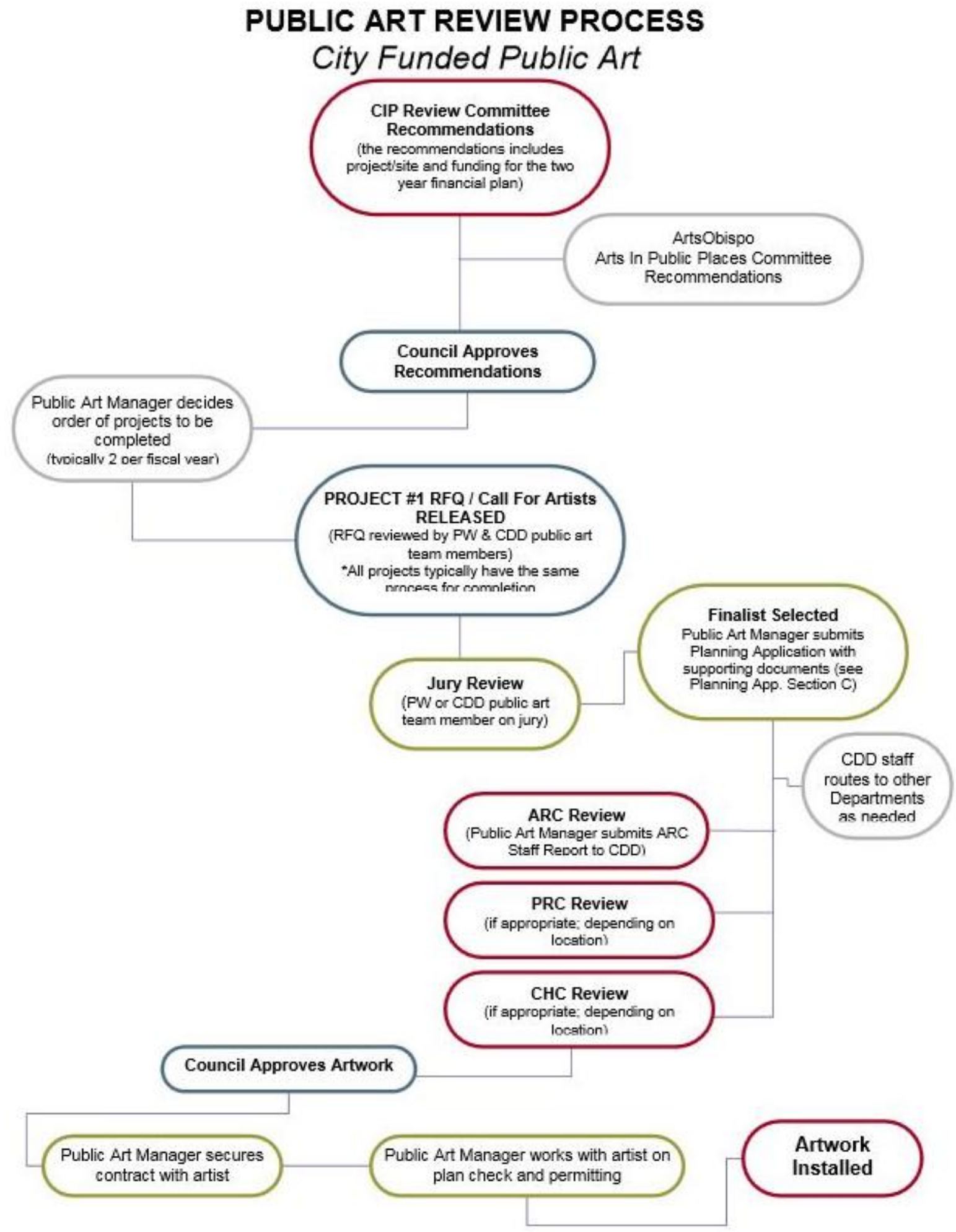

Figure 15: City Funded Public Art Process flow chart (City of San Luis Obispo Parks and Recreation Department, 2011) 
2. Privately Funded Art in Public Places: Private Citizens may donate public art to the City for

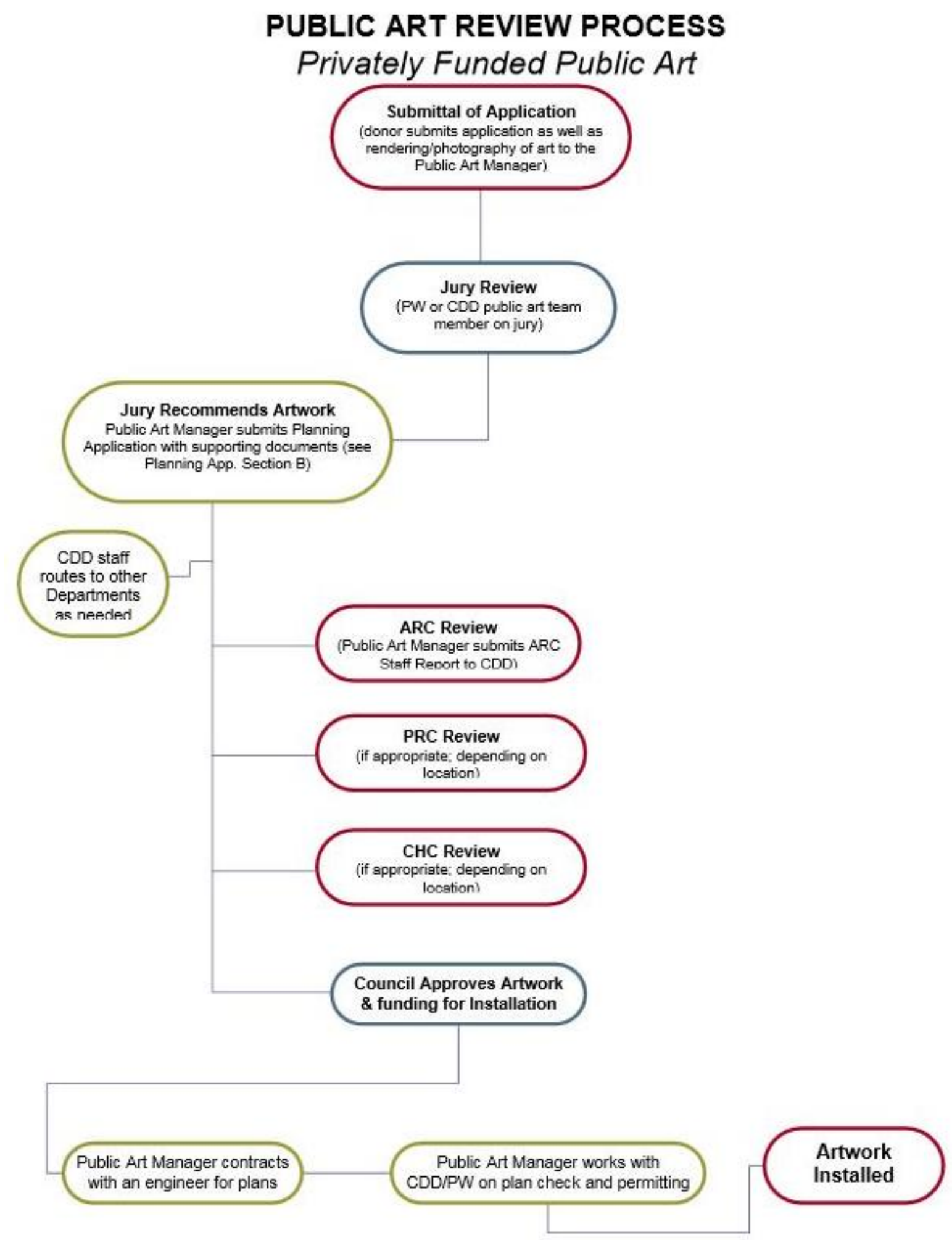

Figure 16: Privately Funded Public Art process flow chart (City of San Luis Obispo Parks and Recreation Department, 2011) 
personal reasons.

3. Public Art in Private Development: The City requires private developers to include public art in their projects valued at one-half of one percent $(.5 \%)$ of the cost of construction over $\$ 100,000$. Optionally, developers may contribute an amount equal to the value of the required art to the City's art-in-lieu account or donate a comparably valued piece of art to the City.

When a developer includes the art as part of the project they work with an artist to install a piece specifically for the development project. The developer has the most input on the process, resulting in less say from the City's public art department (typically part of the Community Development Department or the Parks and Recreation Department). Before going through the necessary approval bodies the developer (usually with the help of a City or a County public arts group) will need to create and distribute an RFP or RFQ for the proposed artwork. This would be a very similar process to contracting a subcontractor. The RFP would include a description of project goals, scope of work \& location, proposal submission requirements, (artists) qualifications, the evaluation process, and what's needed in the submission. In the Artist's Call for the RFP it needs to include 1.) theme 2.) Location 3.) rough dimensions (possibly materials suggestions) and 4.) a budget (this can be a range). The time period that the call for artists/ RFP is open is highly

When the developer pays an in-lieu fee, the funds are added to a City Public Arts Fund to support City-wide public art projects. Public art projects are often included in Capital Improvement Projects.

At this time in the City of San Luis Obispo the modes for public art installation are only formally presented to a the developer during a checklist prepared for the developer to report the achievement of necessary permitting to complete the project. 
4. Matching Grants for Public Art: The City has established a matching grant program to encourage public art. Public art projects receiving matching funds should provide a clear public benefit and level of match, not to exceed 50\% of the cost of the project.

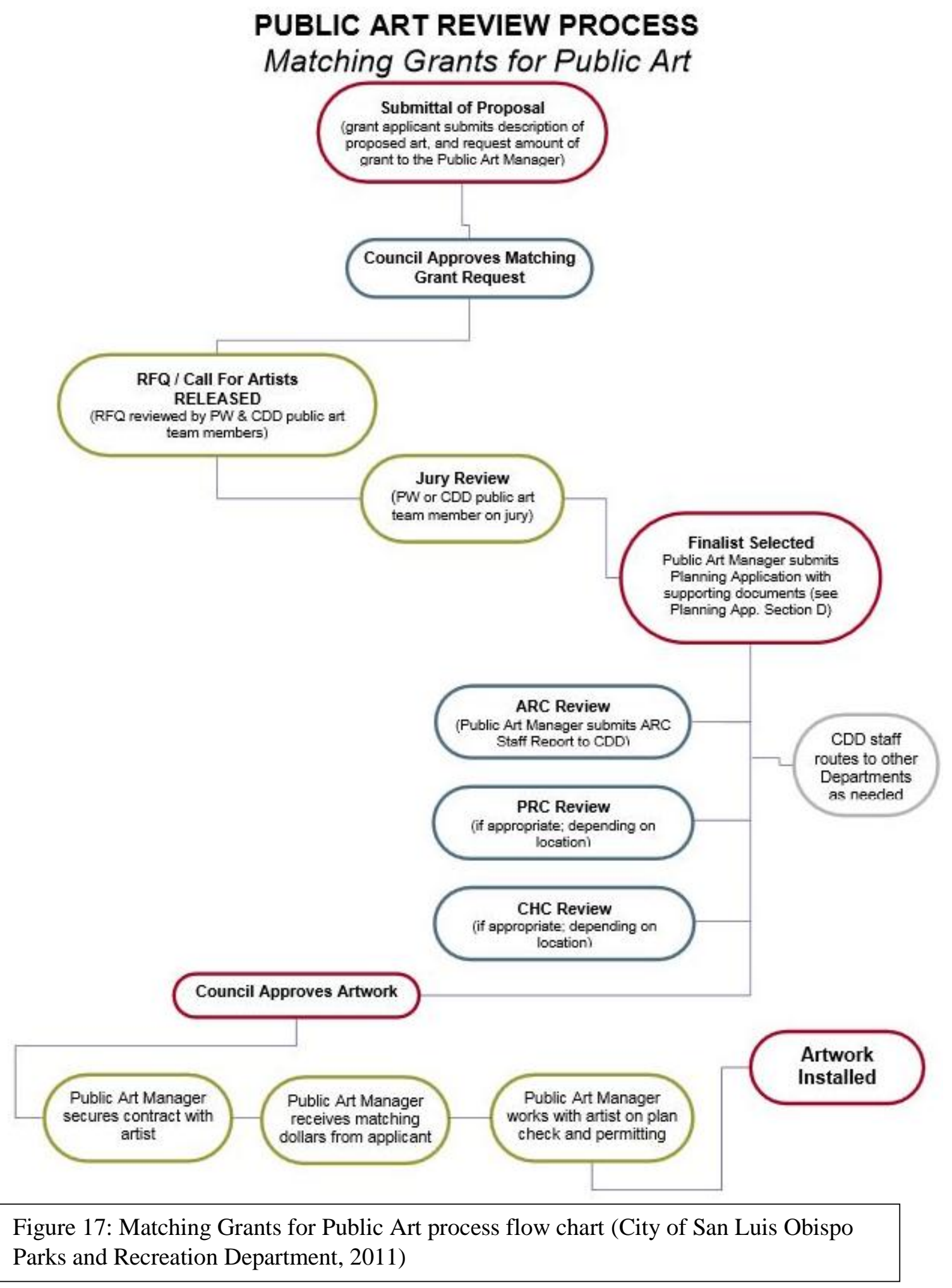


Guidelines for public art are prepared by the Architectural Review Commission and the Public Art Jury. Guidelines include awareness of scale and appropriateness of artwork to existing environment. To be selected and approved all artwork must meet the City's Public Art Guidelines and receive approvals by the appropriate Advisory Bodies and the City Council. The Public Art Maintenance Record is included to ensure that proper documentation is recorded for the agreement to upkeep and maintain the public art piece. The record and a portion of the in-lieu fund are dedicated to care and maintenance of public art pieces. The intricacies of the process described above are further articulated in the expert interviews.

\section{Expert Interviews}

The methodology includes expert interviews of prominent figures working within San Luis Obsipo for the advancement of public art endeavors in the City. Each of the experts encounter public art projects at different steps during the conceptual framework and installation processes. The expert interviews with County Arts Obispo Director, Public Art Director for the City, and Senior Planner provide key insight to the installation process. These interviews were conducted as each of them work as public figureheads in San Luis Obispo to advocate for public art and work within the complex public art installation process.

\section{A. Director of Arts Obispo Interview:}

The first interview with one of the Directors of Arts Obispo described much of how the San Luis Obispo County Arts Council functioned as the local partner of the California Arts Council working to advance the visual, literary, and performing arts through programs that promote public access to the arts, arts in educational settings, local arts planning and collaboration, and opportunities for artists and arts organizations. Arts Obispo serves San Luis Obispo County supporting the arts through many community events, educational programs and artists' collaborations. Events include: Art After Dark, Art After Dark Paso, Arts in Education, Art in Public Places, Artist Opportunities, Open Studios Art Tour (15 years and running!), and SLO 
County Arts Talk Sessions, Mosaic classical music festival, etc. The Open Studios Art Tour, a county-wide event for all the cities in the county, makes an accessible activity for all the area's artists to participate in. The Open Studios Art Tour is hailed as a unique event for how accessible it is, being one of the largest Open Studios in the country, with over 200 artist participating annually. Participating artists open their studios for visitors to tour; the event is unique for its unconventional format, for the way that it gets people excited County-wide; it gets people talking about art, how they like to experience, make, or purchase artwork.

Relating back to the research question exploring the differences in expectations between art administrators, the expectations for the Director for Arts Obispo is for public art and art education accessible to all living in San Luis Obispo County. This expectation is prioritized through the several programs and events Arts Obispo implements making art accessible to all throughout the County.

According the Director successful works of public art are the ones that are interactive, bringing people together when they are placed

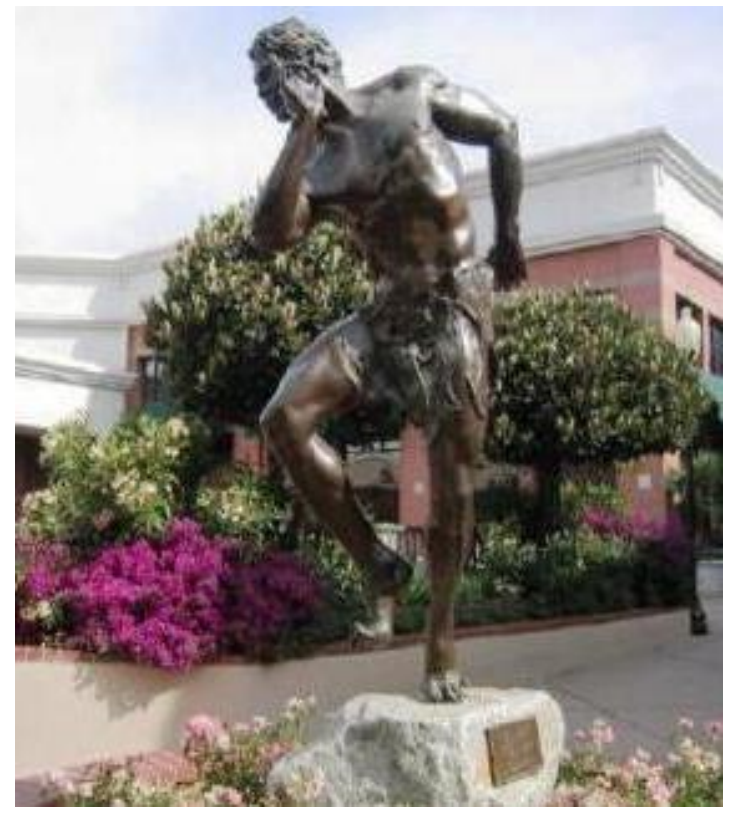

Figure 18: "Puck," Elizabeth McQueen, 2002. San Luis Obispo, CA

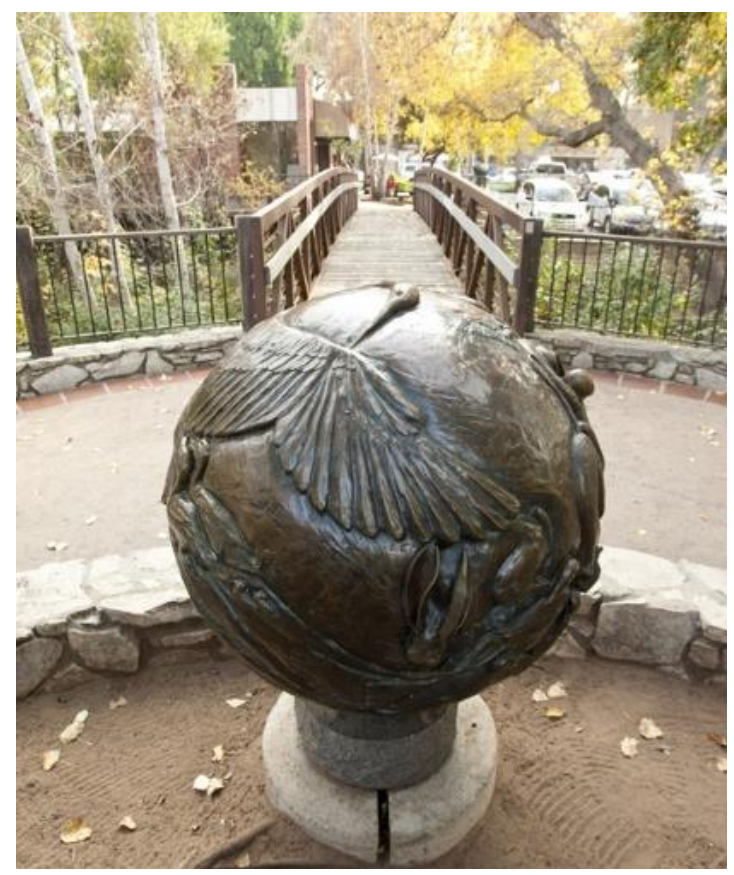

Figure 19: "Web of Life," Sandra Kay Johnson, 1999. San Luis Obispo, CA 
strategically in the right places. A good example of this is "Puck" in the Downtown Centre because he is moveable. "Web of Life" orb statute by Sandra Kay Johnson also exemplary of this interaction, as these pieces are kinetic, inviting people to touch, feel, and learn about the space while interacting with an art piece. Arts Obispo Director noted "The Bean" in Chicago, Illinois as another interactive piece that has such an impact on its surrounding. "It is such an interactive piece"... "They (people) walk under it, they can stand next to it and see their reflection in it." Remarking that "Those kinds of pieces make such a difference in the community" for their ability to facilitate a community discussion and be successful people places calling people to an area, keeping them there, and initiation a conversation about the design and use of urban spaces. These pieces are the "most successful pieces and tend to be my favorite because they get people thinking and talking about it."

The reason there is a public art policy in San Luis Obispo is a result of the partnerships that were forged between the Arts Obispo Arts Council and the City. The conversations that they had roughly 20 years ago set the stage for what is in effect today. They reviewed other municipalities' public art programs- initiating policy for a percent for art program, and making it law. "Let's make this part of our fiber because it is important and we see the value in it!" SLO has such a great program because of the partnership between the County Arts Council and the City working together to write effective policy.

\section{Arts Obispo \& the public art installation process}

A big part of the process for approving and installing public art is prioritizing. Funding will always be a big deal, whether it is from the percent-for-art funding, the in-lieu fee, and these projects take form in different ways as articulated in the charts above. As an advisory body making recommendations, the Arts Obispo committee helps prioritize projects funded by the in-lieu fees, advising the City on what the Art in Public Places committee 
(representative of a number of different parts of the community) wants to see first, and how the City should effectively spend their money.

One of the major stakeholders that is to be acknowledged concerning the design and installation of public artwork are the downtown business owners and the downtown association. Through the formation and work of the Arts Obispo committee there is the opportunity to prioritize projects like the "Box Art" program, which served as instant way of

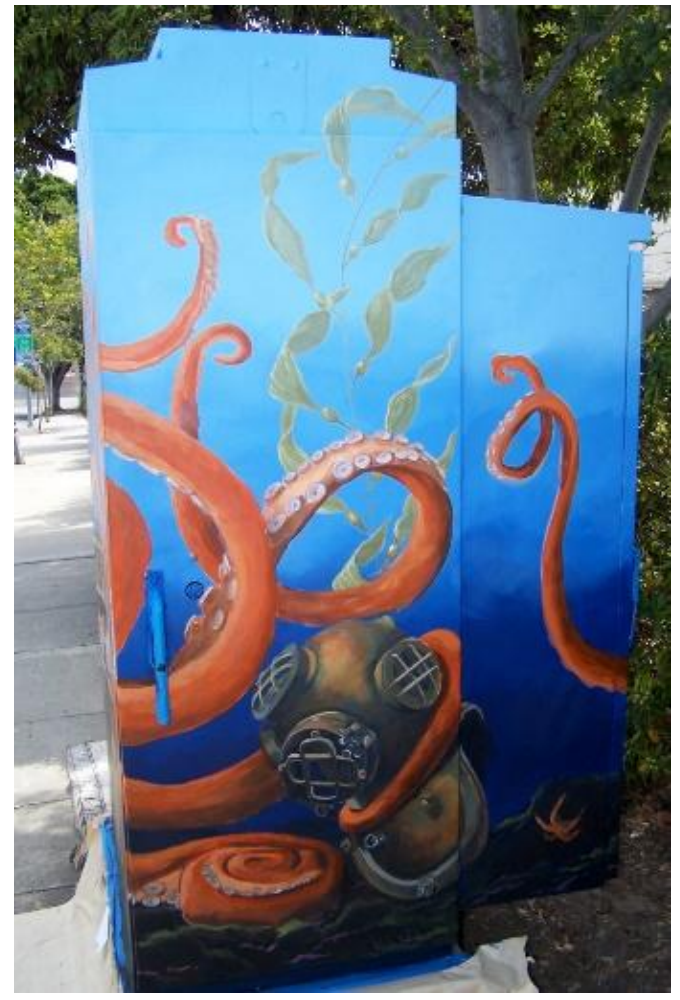

getting art populated around the City.

Figure 20: Painted Box Art at Santa Rosa \& Palm Street, Colleen Gnos, San Luis Obispo, CA

The City of San Luis Obispo's Art in Public Places Program commissioned local artists to create masterpieces on 16 utility boxes in downtown San Luis Obispo and surrounding neighborhoods as part of the "BoxArt" program. The program was so successful after the first round of "installations" that the City expanded the scope of the project to include neighborhoods, commissioning more artists to paint more utility boxes. A printable map and an interactive storyboard map tour in ArcGIS is

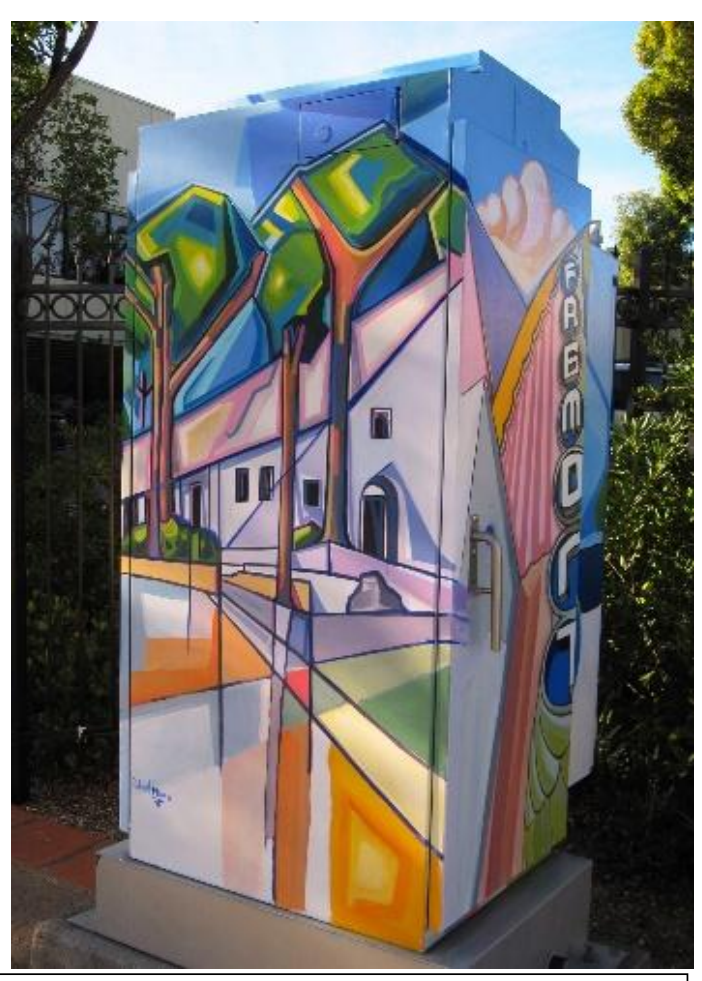

Figure 21: Painted Box Art at Santa Rosa \& Monterey Street, Robert Maja, San Luis Obispo, CA 
available on the City's Parks \& Recreation website. The Art Box project is a unique way to liven up the City's streetscape without costing the City too much, making points of interest for pedestrians and vehicles traversing the downtown area and surrounding neighborhoods. The boxes feed into the larger notion of "placemaking," making unique places that people remember and appreciate.

\section{Potential for Future Projects}

There is much potential for opportunities to include art events and rotating public art in San Luis Obispo's rich artistic tradition, but it comes down to proposals and what's going to work with the City and priorities. Ultimately the process takes time, but there are is passion for the idea of rotating public art. A lot of planning and financing goes into figuring out the logistics for these types of projects that is not involved in the traditional public art installation process. Questions about the financing relates to logistical questions of how often pieces change.

Public art can do so much in defining how people use a space. The hard part is getting developers to see the importance of public art. That's the hurdle. We have a lot of architects that glorify the importance of their materials and architectural form, so they feel they don't need to include public art and will pay the In-Lieu fee. The interview with a Director of Arts Obispo provides insight on the way that public art has trended in San Luis Obispo, what has been successful endeavors, and where programming could have a place shaping the region in the future.

\section{B. Department \& Public Art Program Manager of the Parks \& Recreation Department Interview:}

"Public art is difficult because it is a marriage between municipal government and artists. Municipal government is very structured and policy driven, and it enforces that structure and analysis on what is typically not a very structured process (being an artist and creative). Public art in itself is kind of weird because it does just that! (In merging a structured, 
political process with a creative one.) You're trying to get the creative aspects of art in your community, but you're imposing all these adherence to requirement on top of what is normally a very creative process. It's really a nice balancing act" (Mudgett, M. (2014, March 4). While marveling at the unique crossover it was noted that "Public art is so much more planning than you would have ever thought! Really, that's $95 \%$ of it. The other $5 \%$ is the art" (Mudgett, M. (2014, March 4). The success of public art installations relies on the ability of staff to bring the project through the planning process. The Program Manager articulates that it is important to remember, while public art is ultimately a political action, just as planning is, "Public art should be told as a story, not just reading legal documents" (Mudgett, M. (2014, March 4). These stories express the ideas behind placemaking. Placemaking is a theme introduced to articulate the intangible aspects of a community feel that binds people to a place and makes it unique, giving importance to details in building edifices, the trees lining the street, the width of the sidewalk, and other unique environmental factors. The expectation here for the Department \& Public Art Program Manager for the City of San Luis Obispo is for the marriage of art and planning to be seamless and the process translatable to artists, developers, and administrators alike. This is prioritized through the City-funded public art process where the inlieu funds are collected, saved, and doled out with the discretion of the program manager and advisory boards.

\section{The Public Art Installation Process:}

The public art program that the City adopted in 1990 came about because the City Council supported the initiative. City Council deemed that $1 \%$ of the estimated construction cost of eligible projects in the Capital Improvement Plan should be set aside for public art. The policy encourages the creation and placement of public art throughout the community.

As outlined in the There are three ways that the City can get funding for public art. When development comes in they can 1.) Opt as part of their development to put in public art. If they 
chose to not do that then they 2.) have to pay a developer in-lieu fee. 3.) The public donates art to the city.

The Program Director's part in public art typically deals with the developer in-lieu fund, when developers chose to not provide public art themselves, but pay into a fund to provide artwork. When funding is available the Public Works department will work with the art community and other Master Planning to determine what type of art should be the most appropriate for our community. In the interview the benefits of having an in-lieu fee were acknowledged from the development point of view in that the funds can be collected (in-lieu fees), saved, and rolled over like a savings account to save funds for something really big. This structure gives the Public Art program Manager the flexibility to save the funds available to do a larger project that the City would not be able to accomplish without if they were limited to only using the funds as they come in for each project. This is the case for the skate park in San Luis Obispo and the department has been very conservative with the recommended uses of our fund from the Developer In-Lieu fees because they knew what was coming in year three and four (of the seven year development project) and they wanted to save funding to be able to afford the artistic trees for the park, which the City would not have had the opportunity to do had Parks and Recreation not saved the in-lieu fee funds. This program is advantageous for the flexibility associated with this funding is to have balance and provide the opportunity for developers to choose the option of paying an in-lieu fee.

The option to pay into a developer in-lieu fee requires the developer to pay a percentage based upon the total dollar value of their building (I think it is a $1 / 2$ of a percentage of $\$ 100,000$.) Their developer in-lieu fee gets calculated and goes into a pot of money. If they decide to put art in their project themselves there is an application checklist and every art project, regardless of where it is originating from, has to go through our Architectural Review Commission (ARC) and they review to make sure all public art is in conformance with all City standards and policies and 
ordinances (eg. Lighting ordinances, color ordinances, building ordinances, making sure it fits in with the existing character), so that art goes through the same review process, but that developer walks it through the process because they are providing that art as part of their development.

When it becomes a developer in-lieu fee, staff works together with other departments and the arts coalition to determine what locations would be best for art, what types of art, what dollar amounts are deemed appropriate for that particular project. The project then goes to City Council to determine how much was collected in developer in-lieu fees, this is how staff recommends the use of those fees (the divvying up) for these particular projects and locations. Council given this information you can approve or deny. Once Council approves our funding for certain projects, staff will return with a Request for Proposal (RFP) for a particular project to advertise it out to artists and get application back. Then the whole process starts from there.

An example of the third option is a project for a Roofing Company in downtown San Luis Obispo building for a mural. An artist approached the owners voicing his wanting to do a mural along their wall and the owners supported the proposal. The owners then came to the City said "We'd like to have this. Would the City consider matching some of our donations for this art in order to make it happen?" Even when the art is initiated by the private side (not a developer, but a private person) it still must go through the same Architectural Review Commission (ARC) process. In this case the City agreed that the proposed would be a good use of art and in an appropriate location. The City supported that intent and provided a minimal $(\sim \$ 5,000)$ fund to match the muralist to be able to do that. The project is currently in the process of securing all the advisory body reviews. This project is in two historical districts: The Railroad District and the Old Town District, necessitating review by both the Architectural Review Commission (ARC) and the Cultural Heritage Committee (CHC). Once a contract is awarded to an artist there is a very healthy permitting process that they have to go through with plan checks and engineering programs on top of permitting. This extensive process is in effect to ensure appropriateness with context, structural integrity, and other considerations that impact art in public places. 
The research and interviewing conducted show this to be a convoluted process. The process takes time. Typically projects are looking at a year to 2-year timeframe for public art from the initial thought process to determining funding sources, securing funding approval, developing and administering an RFQ, the art jury process, selecting semi-finalists, presentations, and then approving the art. Only after that process does the art then go through all the necessary advisory council reviews. Contracts are then award and then the permitting application, building inspection, and planning period. Finally there is the fabrication and installation and dedication. This process can take up to two years' time depending on a myriad of factors dealing with the project type and its location. For someone who is not familiar with the process it may seem crazy, but for those familiar with how fast government moves, not so much. This structure ensures that staff is working on every single piece all of the time! The multi-staged process needing several bodies of approval takes that long, especially when involving the community in the decisionmaking process. (Which I would absolutely NEVER advise doing it without it- you can’t!)

The concept of marrying two very different, opposite traits that instinctively would not go together being the stringency of the planning process and the perceived relaxed nature of art is a testament to how strong a City organizational structure is and how strong a community is. (How talented you are as a program manager.) The need for an individual who understands the difference between the two and has experience on the planning and engineering side is essential. (Who work) with a little bit of creativity to "talk the artists' language" and explain the process outlining the municipal government hurdles that are mandatory to go through. The position of public art manager requires taking knowledge and experience of the planning and government process and serving as a liaison to the public and to the artist. The San Luis Obsipo Public Art Master Plan is stages of being drafted. It is hopeful that the Master Plan could address some opportunities for types of temporary and performance art. 


\section{Senior Planner Community Development Department Interview:}

As Senior Planner for the City of San Luis Obispo the main experience with public art in San Luis Obispo is informally known as "shepard-ing art projects" proposed by both City and by private entities through the Architectural Review Commission, serving as the liaison between the City and the Architectural Review Commission. In working for the City in the Community Development Department (CDD) for over 20 years, it is interesting to notice how many pieces have been approved and installed since the implementation of the (public art) program during their tenure with the CDD. The expectation for the Senior Planner in the CDD is to have "successful" relationships between City administrators enacting the process and the advisory bodies providing approval. This is prioritized through creating guidelines for "appropriate and successful" artworks that engage citizens and create unique spaces.

For the Senior Planner the public art pieces that are most "successful" are the ones that have made a difference in their setting, enhancing the human connection in their spaces; citing "Puck" as one of these pieces of artwork for being "fun" and interactive. The Railroad workers statue by the train station is very appropriate for its setting. Also mentioned is Paula Zema's fountain statue at the San Luis Obispo Mission for being very iconic for the City and that while some may have the perception of the piece being "too much like Disneyland," it is quelled by the participatory aspect of the piece.

The Senior Planner walks through the process for City- led art projects. These types of projects begins with an RFQ that gets dispersed, then proposals are submitted, and art jury is formed to make a selection. Then preparations, drawn out models and a mock-up are submitted to planning and then staff takes the preparations to the ARC, having its own criteria to evaluate the pieces by. There have not been too many times that the commission has found something inconsistent with their guidelines, but the ARC does make suggestions about siting of the piece or lighting, landscaping around it. 
It is through complex interactions that public art is a reality, including the work of Grassroots organizations volunteering on an art Jury. The Senior Planner really appreciates property owners who have projects that would prefer to purchase a piece and bring it in, rather than just paying the in-lieu fee. According to the Senior Planner most people opt for the in-lieu fee because it is a simpler process and there aren't the addition regulations and paperwork needed. San Luis Obispo does have a lot of local property owners that want to provide their own art. It is acknowledged that the lack of information for developers on how to contact artists is a place that needs improvement. There is not much guidance provided on the developer's checklist for the process for providing art. Despite these gaps in the process the Senior Planner notes that the jury process is progressive and involving because each time it is not the same gathering providing input on public art proposals. Typically the composition of the jury to the particular piece, which is a good thing. It provides some continuity and oversight on a complex process.

From the City's point of view, generally the preference is to support people that want to provide public art. Though there are times that it really does not make sense to include art. There is the ever-important need to avoid "plop art" and the need to avoid putting a sculpture on a site that is visible from the street where it does not fit with the character of the surrounding area. City workers, jury members, etc need to have some discretion in terms of when they really want to advocate for a particular project to put in a certain art piece. It is appreciated when people (developers/ artists) give placement and context a lot of thought. Attention must be paid to the size and scale of a project whether it makes sense for there to include a piece of public artwork. There are all the downtown projects with Garden Street Terraces and China Town redevelopment, both having these conceptual ideas of where they could incorporate public art. With larger-scale redevelopment projects and public paseos it makes a lot of sense to include public art, in comparison with smaller scale projects. Unexpected art is appreciated, but again has to make sense with the design and scale of the project site. An example of this is the BMW dealership on 
Los Osos Valley Road where the spherical globe sculpture created by Jim Jaccobson; it is unexpected and is not disproportionate to the scale of the existing building footprint, landscaping, infrastructure, etc. Ensuring that a piece of artwork fits with the surrounding environment is essential for the work's success.

The Public Art section of design guidelines talks about guidelines for private projects. It talks about the City encouraging the incorporation of public art projects and how the program works. It is specific that the applicant submit the following information for City review and approval about preliminary ideas for public art. We've had people that wanted a public art feature that's visible from the street. All of these considerations relates how complex of an issue public art is in consideration of public art pieces on private property, but installed to serve the larger community must all be subject to ARC review.

The complexity of the process for installing public artworks in San Luis Obispo is the reflection of many stakeholders coming together to agree upon a piece of artwork that fits within the existing built environment. There is a lengthy permitting process to meet the Conditions of Approval before anything can be installed. Public art pieces must meet structural requirements, obtaining a building permit prior to installation- meaning they are secure and able to withstand wind loads, being stable and safe for all people viewing them. Lighting an electrical needs are to be addressed with consideration of the City's Night Sky Ordinance, ensuring that all lighting be directional and shielded. Pieces that are elaborate and have kinetic structures or water elements (like the feature planned for the corner of Higuera and Marsh Street) have to be reviewed by several jurisdictions. The process of bringing one project concepts and design to several bodies for review initiates a complex procedure that would not be as successful without each level of review. 


\section{\#Public Art Is Art After Dark “\#Public Art Is” Community Interaction:}

To address the limitations that a traditional survey has on gathering "data" in the form of public opinions regarding the very diverse nature of public art, I created a creative surveying project to extract common sentiments and inclinations towards public artwork in San Luis Obispo, CA. \#PublicArtIs was an opportunity for the San Luis Obispo community to come and give public comment on what public art does for the public spaces around them or to various places they have visited. Friday, March 7th, during the monthly scheduled Art After Dark event I set up several comment boards at various "gallery" spaces downtown for the San Luis Obispo public to comment on what is meaningful, profane, exciting, celebrated, misunderstood, a myriad of other expressions for what public art does for a community! \#Public Art Is, a brainstorming activity to get people thinking about what is important, identified what is celebrated, how people see art, and how things should change in the future. The project was inspired by urban planner/visual artist Candy Chang whose work brings together planning and artistic endeavors to gather public comment and opinion influencing planning, be it long-range or an event to "bring City hall to the community." The process breaks down bureaucratic boundaries to elicit community interactions that impact planning decisions. This intent is seen in her projects "Before I Die" "I Wish This Was" and "Looking For Love." These projects worked to empower individuals within a community by gathering a community-collective voice through the public comment process. I took note of how widely received these initiatives were and created a similar process for identifying a community vision for what public art means, does, and looks like to the participants of Art After Dark in San Luis Obispo.

The surveying event took place during the monthly Art After Dark event. Six \#PublicArtIs boards were set up around downtown San Luis Obispo at the following locations: Art Central, Fromagerie Sophie, The Gallery at the Network, HumanKind Fair Trade, Linnaea's Café, and the San Luis Obispo Museum of Art. Appendix _ shows a map of the event locations highlighted on 
the Art After Dark official map. Participants were asked to provide comments by writing a word or phrase or illustration following the prompts "I think," "I see," and "I want"... public art.
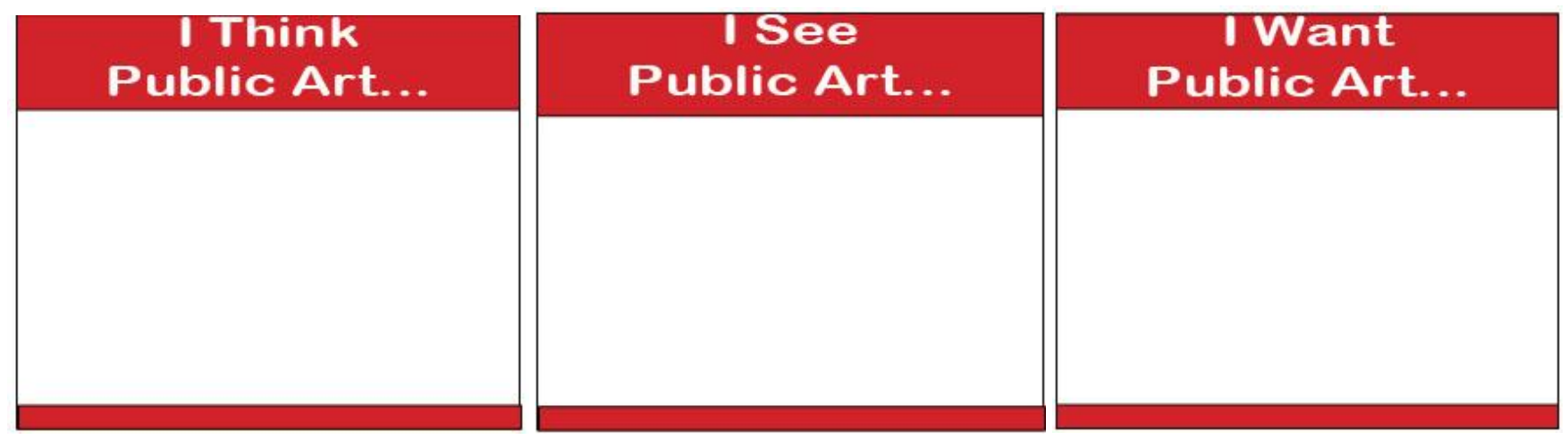

Figure 22: "I Think Public Art..." et. al. Materials for Art After Dark Community Surveying Activity

Responses from the \#PublicArtIs boards provided a wide range of thought about the role of public art, the intended audience, and what it does for a space. There were a total of 272 "nametag" sticker responses posted on the six \#PublicArtIs boards. The majority of all responses to the prompts (I think, I see, \& I want Public Art) were positive responses. Whether the respondents answered in this way because it was a public event and they wanted to submit a "culturally accepted response"/ culturally conditioned response or they actually took that position, I can only postulate, but the overall positivism resulted in many "ideal" or "unrealistic responses." Idealist responses e.g. "public art should be everywhere" were common, and may have been so because the boards were so public.

Responses could be categorized into several themes, these being public art impacting the local "Community," public art being a form of "Expression," eliciting "Emotions," performing certain "Actions," initiating a "Discussion" and identifying locations for "Where" public art is appropriate and appreciated. Charts recording all of the responses in subcategories are included in the Appendix. Responses that noted "community" being tied to public art related the function of public artwork to being a community-builder and enriching a sense of community within a town. 
Responses dealing with "expression" bring up ideas for personal expression versus community expression, and humanity. Responses relaying "emotions" as major core for public artwork articulated the beauty of art in public settings and unique qualities of juxtaposing art with urban life. Responses that evoked an "action" response to the Art After Dark public in SLO meant articulating what an art installation does for a space, how it acts as a community builder (building a sense of place), the ability to show unique talents, how it is funded, its role as an educational tool, physical examples of what it looks like, and the need for it to be interactive and therapeutic.

Responses dictating public art to be a "discussion" emote that public art works to create dialogue, that it is provocative and causes individuals to take pause and think about their environment.

Responses for "where" people

would like to see artwork elicited an overwhelming “Everywhere!” These responses noted that public art endeavors should be increased and better supported, with the overarching theme that more public art is wanted and needed in urban landscapes.

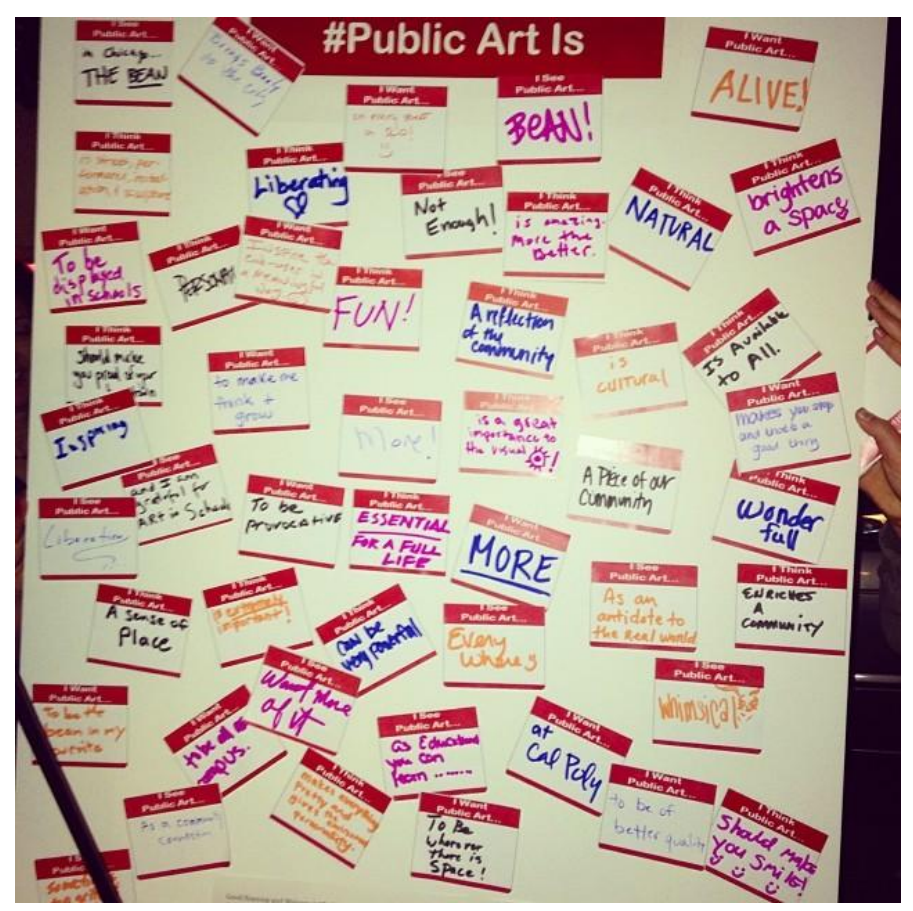

Figure 23: "\#PublicArtIs" board part of community surveying, 2014.

The process of bringing surveying to the public during an already-established event ensured successful participation. The project was able to collect responses and comments from a widerange of participants at the event. It initiated a discussion about public art, a topic not generally in the forefront of daily thoughts. The activity caused people to stop and think about where they see public art, what it does for them, where it is appropriate, who it empowers, and a flood of other 
questions. As the Americans for the Arts writing states: "Public art activates the imagination and encourages people to pay attention and perceive more deeply the environment they occupy" (Americans for the Arts- Why Public Art Matters). The goal of the activity was to initiate a public dialogue. The specific responses were insightful, but the overarching objective was to get people to think about the space they inhabit every day and reflect upon what is meaningful and what creates good "people-places" attracting people to them and keeping them there. The opportunity to continue projects like \#PublicArtIs empowers the community, keeping in mind that their opinions should impact future development. 


\section{CHAPTER V. Conclusions}

\section{Closing Remarks \& Recommendations}

Much is written about the importance of public art initiatives on the cities they decorate. The Americans for the Arts Public Art Network Council published a bulletin on "Why Public Art Matters.”

Cities gain value through public art- cultural, social, and economic value. Public art is a distinguishing part of our public history and evolving culture. It reflects and reveals our society, adds meaning to our cities and uniqueness to our communities. Public art humanizes the built environment and invigorates public spaces. It provides an intersection between past, present, and future between disciplines, and between ideas. Public art is freely accessible (Americans for the Arts- Why Public Art Matters).

The functions of public art bring about many social connections through the installation of art in urban settings. The blending of artistic process and civic permitting legitimizes the place for public art right next to projects like capital improvement projects that are necessary for the advancement of cities, keeping infrastructure up to date. "Public art brings artists and their creative vision into the civic decision making process. In addition to the aesthetic benefits of having works of art in public places, artists can make valuable contributions when they are included in the mix of planners, engineers, designers, elected officials, and community stakeholders who are involved in planning public spaces and amenities" (Americans for the ArtsWhy Public Art Matters). The Public Art Program Manager describes these relationships giving weight to the uniqueness of the partnerships and being a reflection of the strength of the City's organization. Through these partnerships a city can focus on art and aesthetics to enhance quality of life, and not necessitating that all of the city's funds be dedicated to the maintenance and upkeep of public infrastructure. The City's Public Art program shows the prioritization of art to enhance the quality of life for who live and visit the area.

The current situation necessitates more information to be relayed between the differing stakeholders in the process. There needs to be clearer communication between developers and artists regarding the public art planning process in cities! There needs to be a better 
communication process between developers, public arts organizations (like Arts Obispo), planning technicians, and the Architectural Review Board. The process for installing public art is complex and involves approval from an Architectural Review Board, a Public Art Panel, and City Council. For seasoned developers (and Artists!) who have navigated this process before it does not seem so daunting, but for new developers (and artists new to an area) the process is convoluted and increased information provided by the City would help immensely. The following recommendations outline strategies for closing the gap in knowledge and creating a clearer, more easily understood process for developers, artists and administrators alike.

In San Luis Obispo the role of managing the public art is absorbed in the Department \& Public Art Program Manager position. As stated earlier it is unique for the public art program to be under the Parks and Recreation Department rather than the City Manager's office. Meaning that managing the Public Art Program Manager became one of the program responsibilities on top of supervising staff, youth sports, youth services, and community promotions. This is not a single-level of responsibility position, but a balancing act. The Public Art Program Manager noted for having such a mature, long-standing public arts program it is interesting that there is no dedicated staff person with the sole job of managing the arts program. Potentially with the creation of the Public Arts Master Plan for the city a designated position could come about as well. While the City of San Luis Obispo is celebrated for being unique, it is in a bubble, an island that is too far away from Los Angeles or San Francisco to be impacted by development or movements there. While cities closer to those hubs can easily contract out services or partner and create mutual agreements, the City of San Luis Obispo is very limited in opportunities to do just that; adding to the island notion making municipal government challenging. These issues impact public art as well. Even though the areas has many local artists, San Luis Obispo does not have the same kind of opportunities and local artists' pool as larger metropolitan areas do, citing the example of a public art program that works down in Newport Beach being able to work with artists in Huntington Beach or Dana Point or elsewhere and that by being geographically close to 
these areas, there are infinitely more resources available than available in San Luis Obsipo. The fact is that San Luis Obispo does not look to the Five-Cities or Grover Beach. San Luis Obispo is the "leader" of the Central Coast and it is very important for the City to maintain a unique feel.

In the current process the developer is responsible for working with an architect to develop a project design and proposal to be approved by City Council and the Planning Commission. They secure funding to develop the project. Developers are then responsible for working with the appropriate office to secure necessary building permits. The developer oversees the construction of each phase of the project and if installing public artwork. Public arts organizations (as ARTS Obispo) develop RFP's and work with local artists. They will most often be part of Public Art Panels, serving as an advisory board for specific art projects. The Public Art Panel was established to review all City-wide art with a wide range of participants to include: the property owner, representatives of the County Arts Council, members of review boards, and community members. By submitting each process to such a scrutinized review process it is determined that the project will be successful in its environment.

Policy Recommendations include options for prioritizing rotating/ transitional works in San Luis Obispo's downtown core. These works are categorized as events and must be planned for accordingly. This could be in the form of a zoning overlay that would prioritize events ensuring that planning for the events could cut as much red tape as possible to make the events feasible, work within the existing infrastructure, and be exciting to the community.

Based upon the research conducted in this report and the many conversations informing the report it is advised to conduct regular evaluations of the public art availability to continually find out what the public enjoys and what they would like to see next. This process could be structured in a number of different ways. From continued events like \#PublicArtIs to reaching out to community groups and assessing what is meaningful. The \#PublicArtIs surveying activity received no cynical responses. The activity took place during Art After Dark and the participants 
took part in the activity while they were out enjoying the art exhibits. If activities like \#PublicArtIs are to be continued they would need to be restructured to reach a more diverse public.

There is typically a typology for public artwork dealing with the physical object placed in the public sphere and the notion of time. In shifting this paradigm to include a more expansive comprehension of what, where, and how public art could shape its environment, the discussion would lead to new guidelines and different kinds of art, not simply physical and permanent works, populating the streets of San Luis Obispo.

It is important to create "zones" for artwork and people to come together. This type of project is exemplified in the "Ballroom Luminoso" piece by Joe O'Connel and Blessing Hancock in San Antonio, TX. "Places with strong public art expressions break the trend of blandness and sameness, and give communities a stronger sense of place and identity. When we think about memorable places we think about their icons" (Americans for the Arts- Why Public Art Matters). It is also exemplified in the new Skate Park to be constructed in San Luis Obispo. ** Public art memorializes locations and events. The process for public art installation is involved to ensure that projects are appropriate matches for the existing environment. This field is unique for involving many parties to review design and placement of art, to avoid "plop art" to create something meaningful that is reflective of a community environment. The opportunity for urban planners to partner with artists and developers under the review of community organizations shows the potential for collaborations to enhance the quality of life in cities, emphasizing the importance in an urban landscape.

The myriad of public art exhibitions, projects and initiatives around the world show the wide array of opportunities and the numerous ways that art can work to enhance urban landscapes. One way to expand the opportunities for art to take shape is to explore themes of temporality and what is "allowable." The boundaries for this were explored earlier in the project Tour Paris 13 with 
street artists working in collaboration to transform a deteriorating building into an exhibit in the last days of its existing, giving the opportunity to reflect on what was once a functional home, but could now be an artistic endeavor. The exhibit attracted thousands of visitors, being one of the biggest artistic exhibitions the world has ever seen. This project was so unique for being a temporary installation adorning the walls of the run-down apartment building in the last days of its existence, and for being an encouragement of "street art," a typology of art that has been looked down upon and not typically celebrated. This begs questions of what is accepted \& what is not, asking what is profane and what is sacred and celebrated. This example shows the breadth of opportunities and how communities could allow for artwork that is innovative and incredibly empowering.

Planners need to open the framework for more and varied artist opportunities. Giving planners more of a frame to work within to ask questions about what is possible and how to proceed forward. The opportunity to expand the framework for opportunities to include a widerrange of accepted or appropriate works to include temporary installations, events, and performances could be part of the new Public Art Master Plan for the City of San Luis Obispo. 


\section{BIBLIOGRAPHY}

(2013, October 25). Retrieved from The Telegraph :

http://www.telegraph.co.uk/news/worldnews/europe/france/10403913/Street-artists-turncondemned-Paris-tower-in-to-sprawling-art-installation.html

Americans for the Arts. (n.d.). Why Public Art Matters . Public Art Network Council: Green Paper, pp. 1-4.

Americans for the Arts . (2014). Retrieved from Public Art Network :

http://www.americansforthearts.org/by-program/networks-and-councils/public-artnetwork

Baca, J., \& Leicester, A. (1992). Raising community consciousness with public art: Contrasting projects. American Art, 9(1), 62-81.

Barnett, T. (2000). Dialogues in public art. The Oral History Review, 28(2), 162-164.

Beardsley, J. (1981). Art in Public Places: A survey of community-sponsored projects supported by the National Endowment of the Arts . Baltimore, MD: Partners for Livable Places .

Brenson, M. (2001). Visionaries and outcasts: The NEA, congress, and the place of the visual artist in America. New York, NY: The New Press.

Calo, C. (2012). From theory to practice: Review of the literature on dialogic art . Public Art Dialogue, 2(1), 64-78.

Chang, C. (2014). Retrieved from Candy Chang Projects : http://candychang.com/projects/

City of San Luis Obispo Parks and Recreation Department. (2011). SLO Public Art Policies \& Procedures Manual. San Luis Obispo.

Crane, D.A. (1964). The Public Art of City Building. Annals of the American Academy of Political and Social Science, 352, 84-94.

Culture Now . (2014). Retrieved from Museum Without Walls : http://culturenow.org/

Cusick, J. (2005). Designing a public art plan: How to structure a process and a product to meet your needs. In B. Goldstein (Ed.), Public Art by the Book (pp. 4-11). Seattle, WA: University of Washington Press.

Deutsche, R. (1996). Evictions: Art and spatial politics. Cambridge, Massachusetts: The MIT Press; Graham Foundation for Advanced Studies in the Fine Arts.

Fallon, M. (2012). An arts funding revolution. Public art review, (47), 38-41.

Finkelpearl, T. (2000). Dialogues in public art. Cambridge, Massachusetts: The MIT Press

Goldstein, B. (2005). Public Art By The Book. Seattle : Americans for the Arts in association with Univeristy of Washington Press . 
Gombrich, E. H. (1995). The story of art. (16th edition ed). London, England: Phaidon Press.

Grodach, C. (2009). Art spaces, public space, and the link to community development.

Community and Development Journal, 45(4), 474-493.

Hall, T., \& Robertson, I. (2001). Public Art and Urban Regeneration: advocacy, claims and critical debates. Landscape Research, 26(1), 5-26

Hartzell, J. (2013, December 2). Personal Interview.

Hein, H. (1996). What is public art?: Time, place, and meaning. The Journal of Aesthetics and Art Criticism, 54(1), 1-7. Retrieved from http://www.jstor.org/stable/431675

Horowitz, G. (1996). Public Art/ Public Space: The Spectacle of the Tilted Arc Controversy. The Journal of Aesthetics and Art Criticism, 54(1), 8-14.

Irwin, R. (1985). Being and Circumstance . Larkspur Landing, CA : The Lapis Press.

Kates, N., \& O’Hare, M. (1987). Tacoma Neon Wars. Harvard Kennedy School.

Keithline, E. (2013). Public art. Art New England, 34(2), 26-28.

Kirchberg, V. (2004). Structures of corporate arts patronage between the world wars: A case study of the corporate leader p. s. du pont. Journal of Arts Management, Law, and Society, 33(4), 263-280

Knight, C.K. (2008). Public Art: Theory, Practice and Populism. Oxford: Blackwell Publishing.

Landry, C. (2012). The City as a Living Work of Art. Public Art Review, (47), 19-20.

Love, M., \& Love, T. (Directors). (2007). Much Ado About W: Art Wars of Santa Barbara [Motion Picture].

Magie, D. President's Committee of the Arts and the Humanities, (1997). Arts funding into the 21st century. Washington, DC: U.S Government Printing.

Markusen, A., \& Gadwa, A. (2010). Creative Placemaking. Washington, DC: National Endowment of the Arts.

McLennan, D. (1994, Sep 08). ARTS: CITY BOOKLET GIVES GUIDELINES FOR PUBLIC ART. The News Tribune Retrieved from http://ezproxy.lib.calpoly.edu/login?url=http://search.proquest.com/docview/264530849?accounti $d=10362$

Miles, M, (1997). Art, Space and the City: Public Art and Urban Futures. London and New York: Routledge. 
Mudgett, M. (2014, March 4). Personal Interview.

National Endowment for the Arts . (2014). Retrieved from http://arts.gov/

O'Connell, J., \& Hancock, B. (2013). Encounters with Public Art v.2 . Tuscon, AZ .

Pimlott, J. Review of Binkiewicz, Donna M., Federalizing the Muse: United States Arts Policy and the National Endowment for the Arts, 1965-1980. H-Pol, H-Net Reviews. July, 2006. http://www.h-net.org/reviews/showrev.php?id=12071

Ricci, P. (2014, April 10). Personal Interview.

Roberts, M. \& Marsh, C. (1995). For Art's Sake: public art, planning policies and the benefits for commercial property. Planning Practice and Research, 10(2), 189-198.

Sharp, Joanne, Venda Pollock, and Ronan Paddison. "Just Art for a Just City: Public Art and Social Inclusion in Urban Regeneration." Urban Studies . 42.5/6 (2005): 1001-1023. Print.

Vickery, J. (2011). Art, public authorship and the possibility of re-democratization. In Visual Culture in Britain. Routledge.

Willett, J. (1967). Art in a City . London: The Shenval Press . 


\section{Appendix}

Appendix 1: Art After Dark \#PublicArtIs Activity Boards

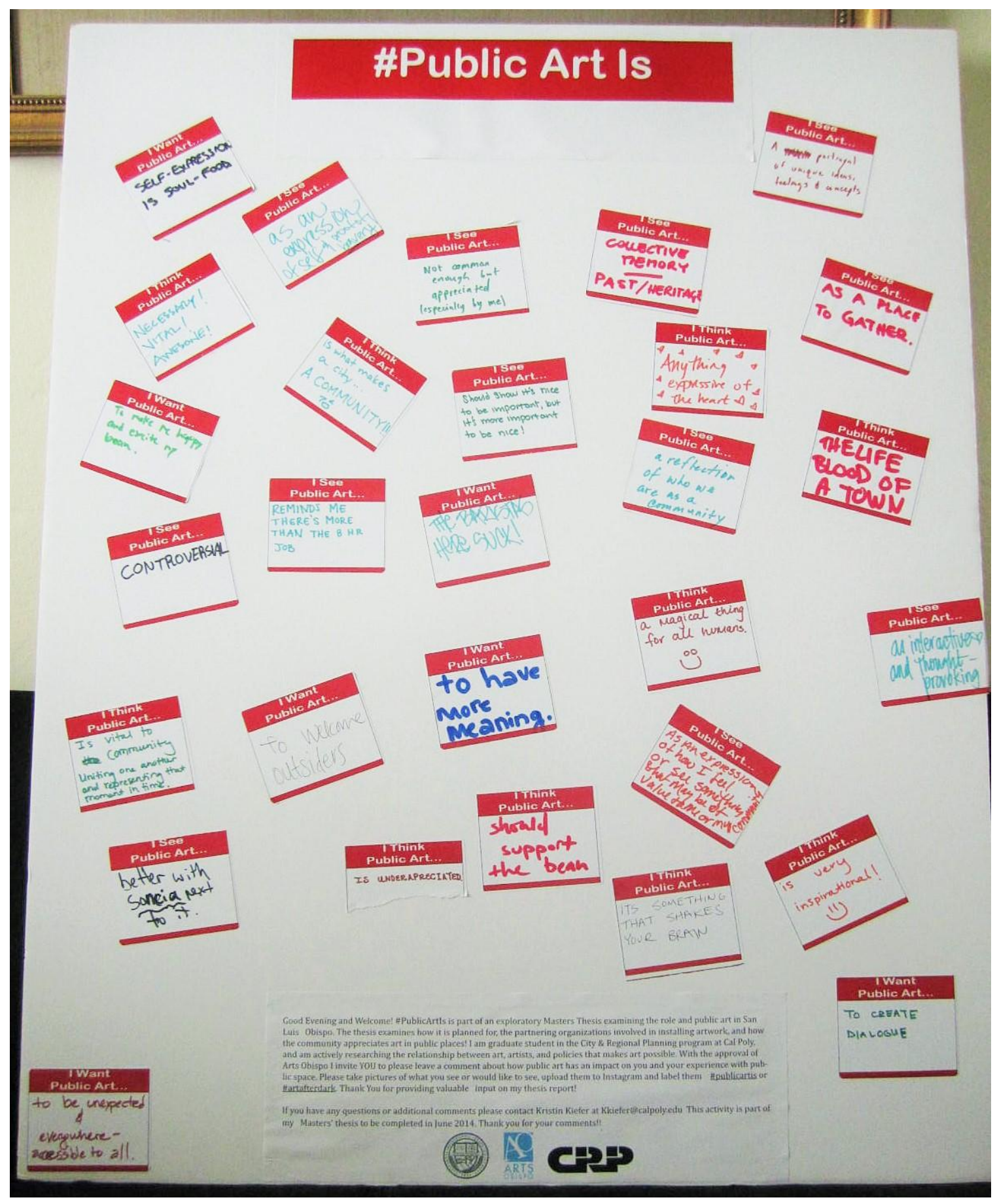




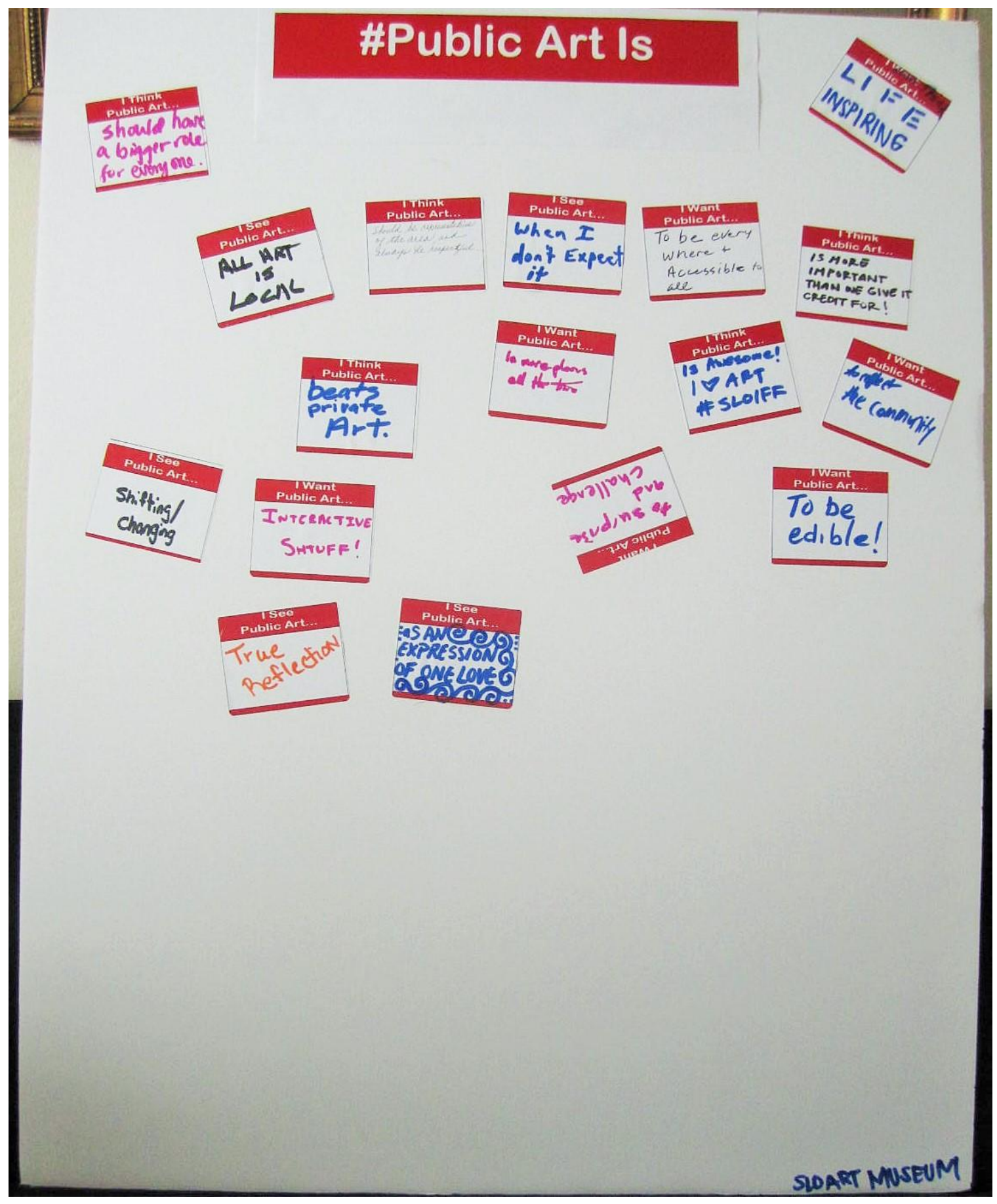




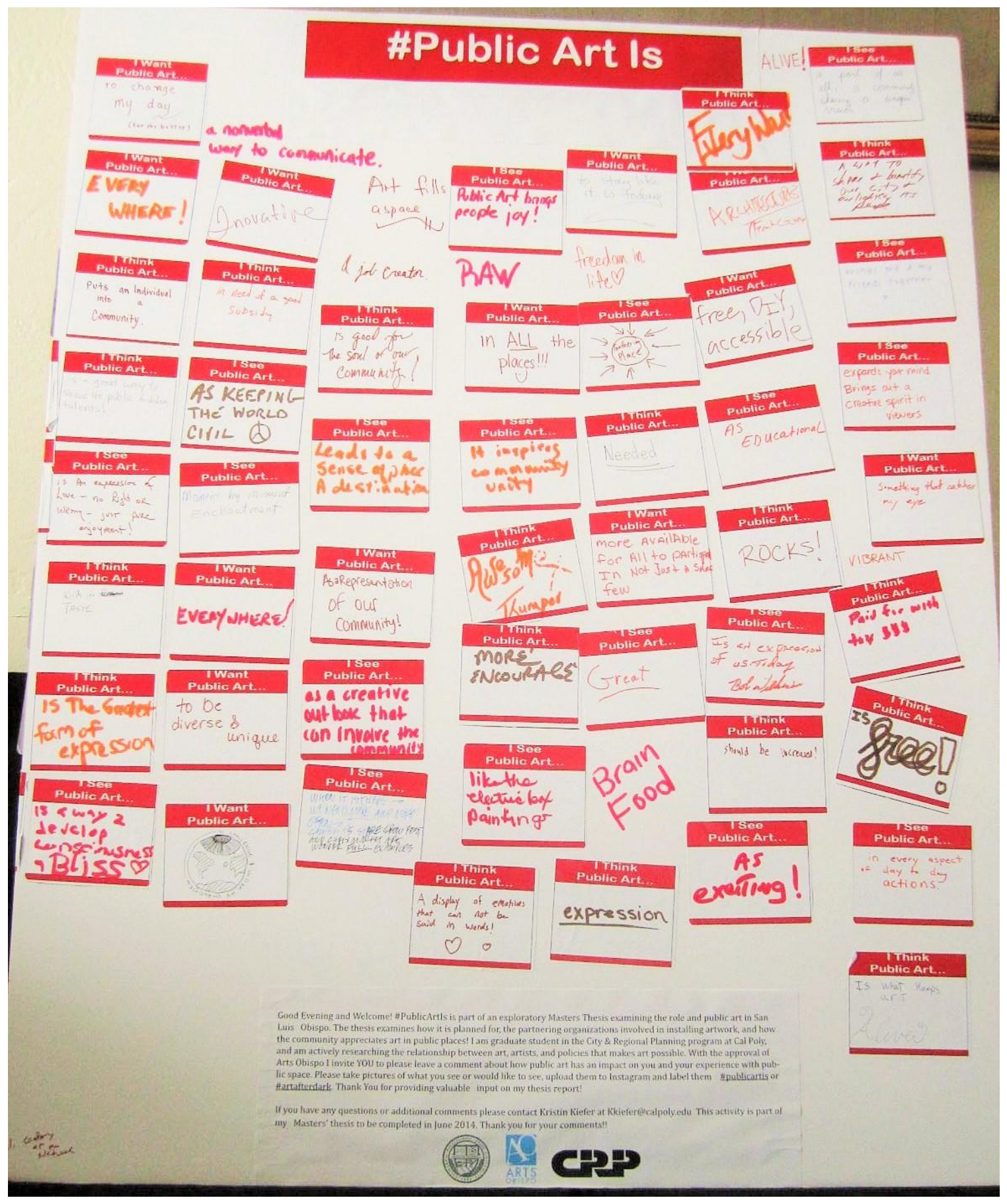




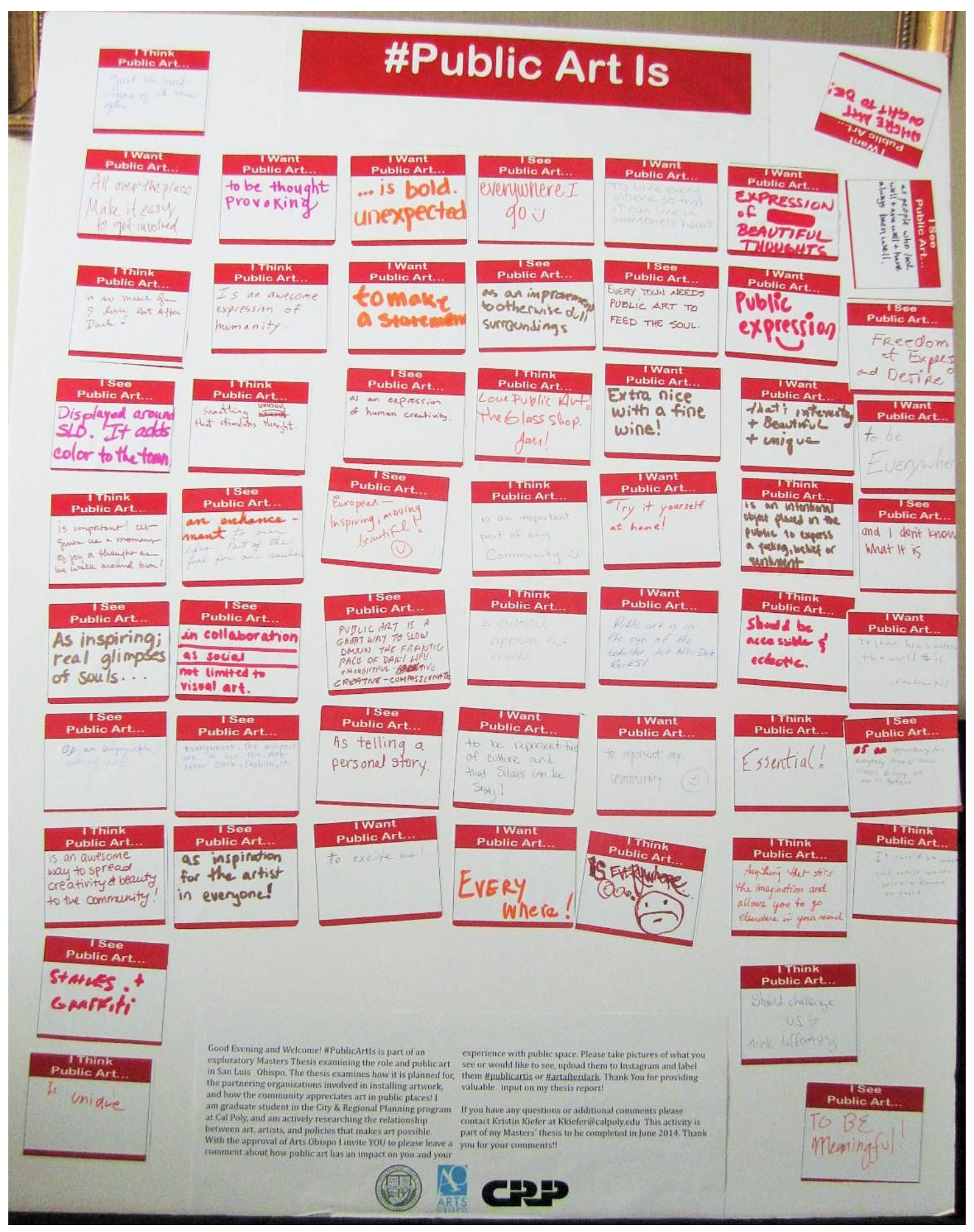




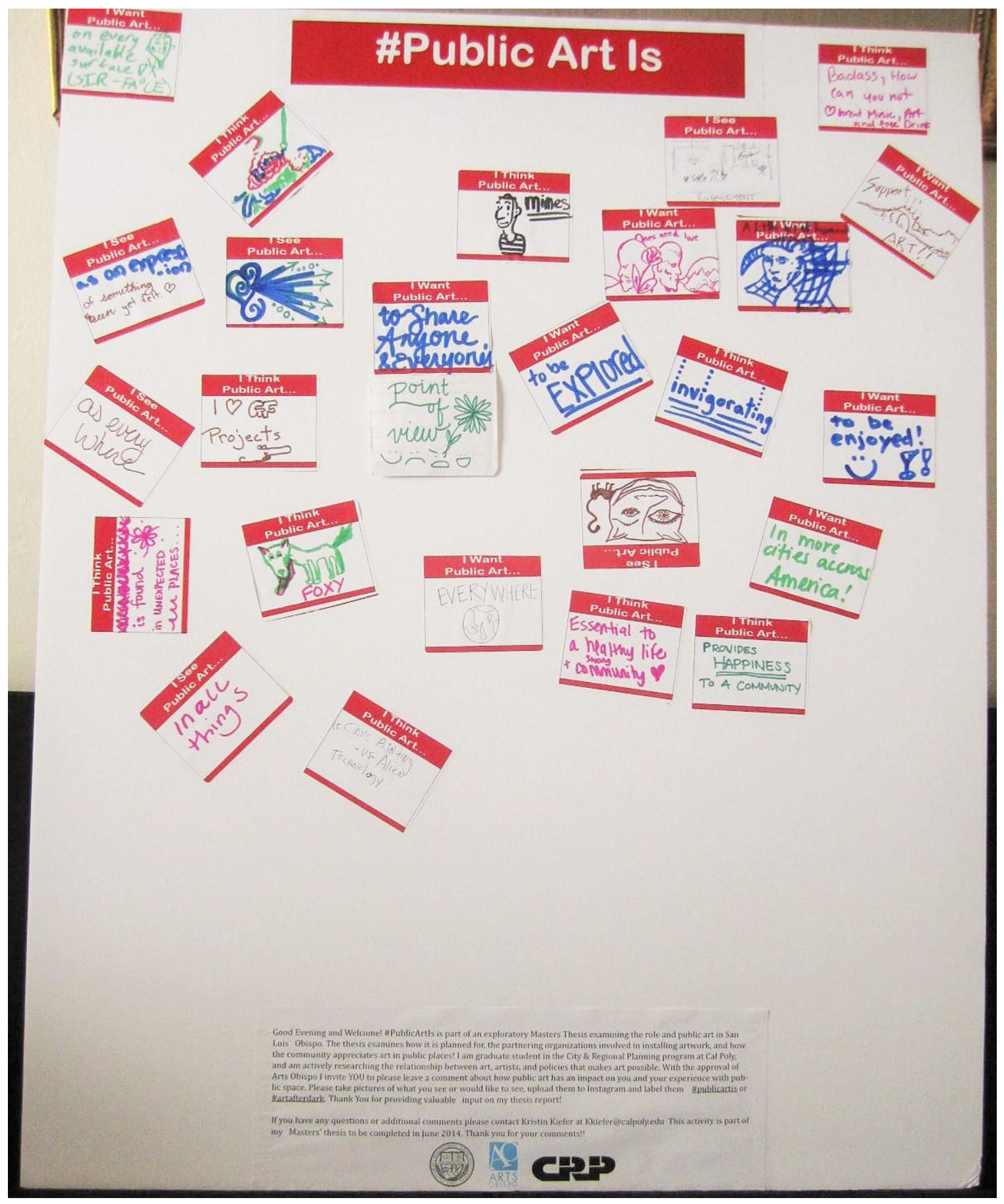




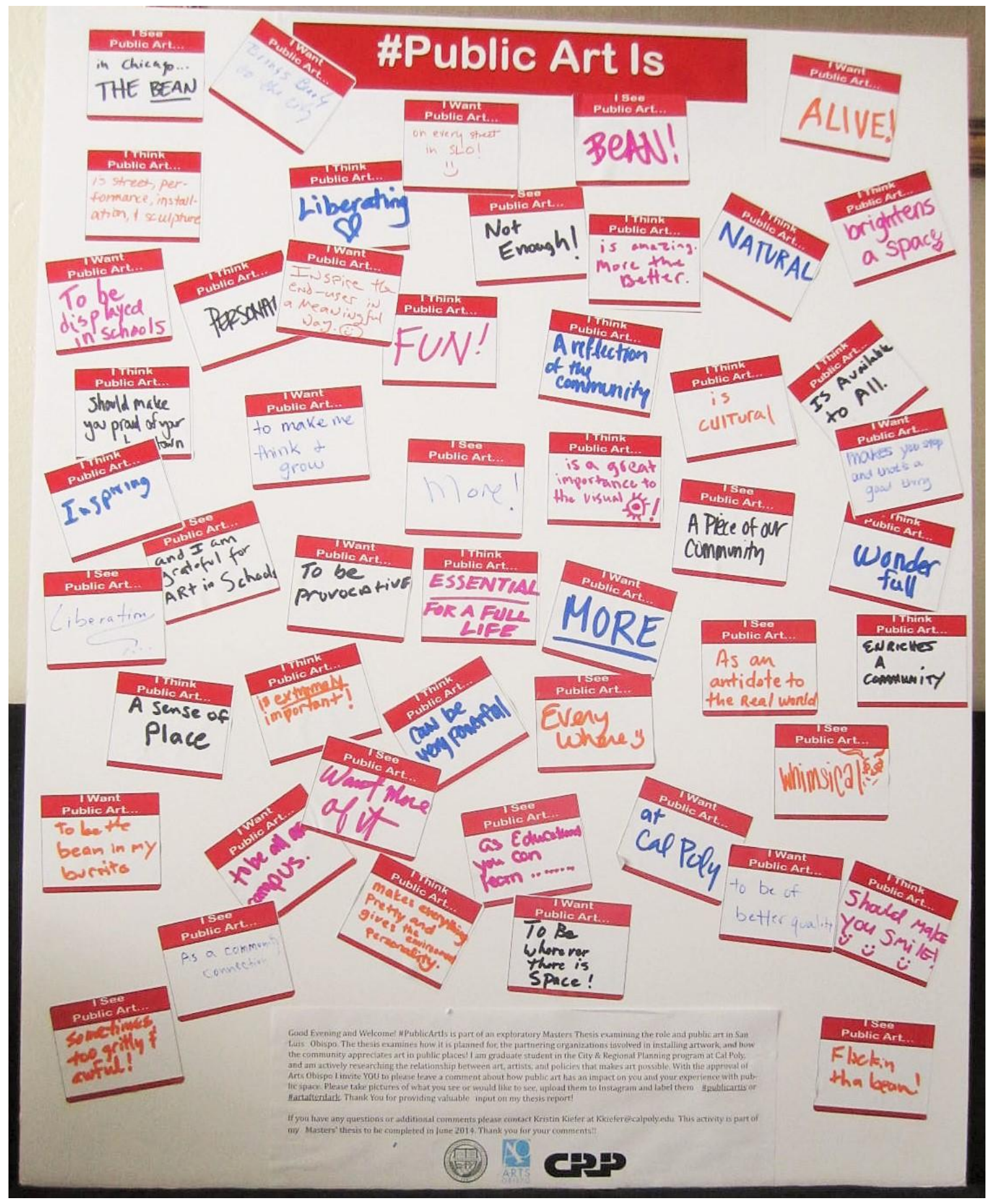




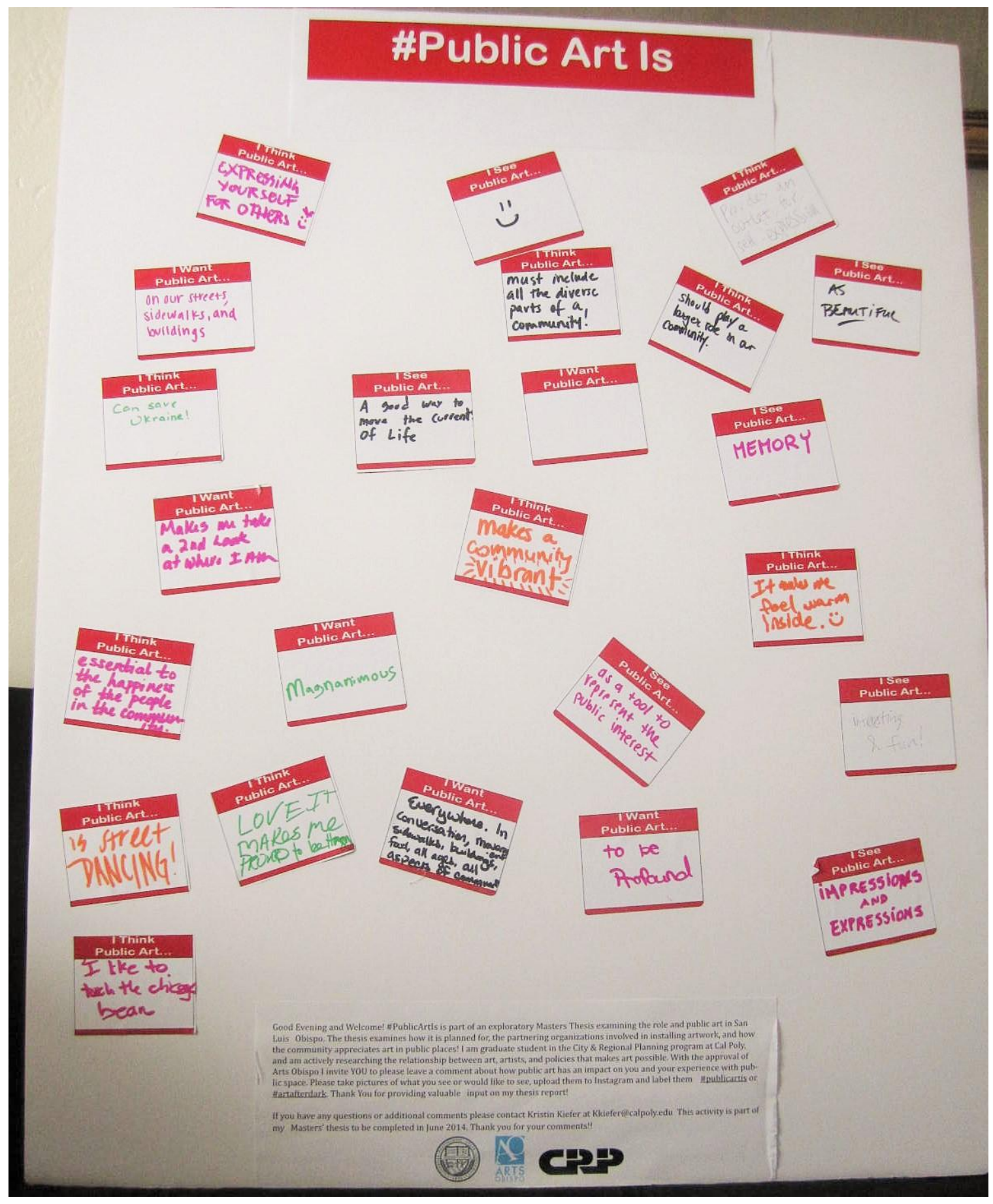




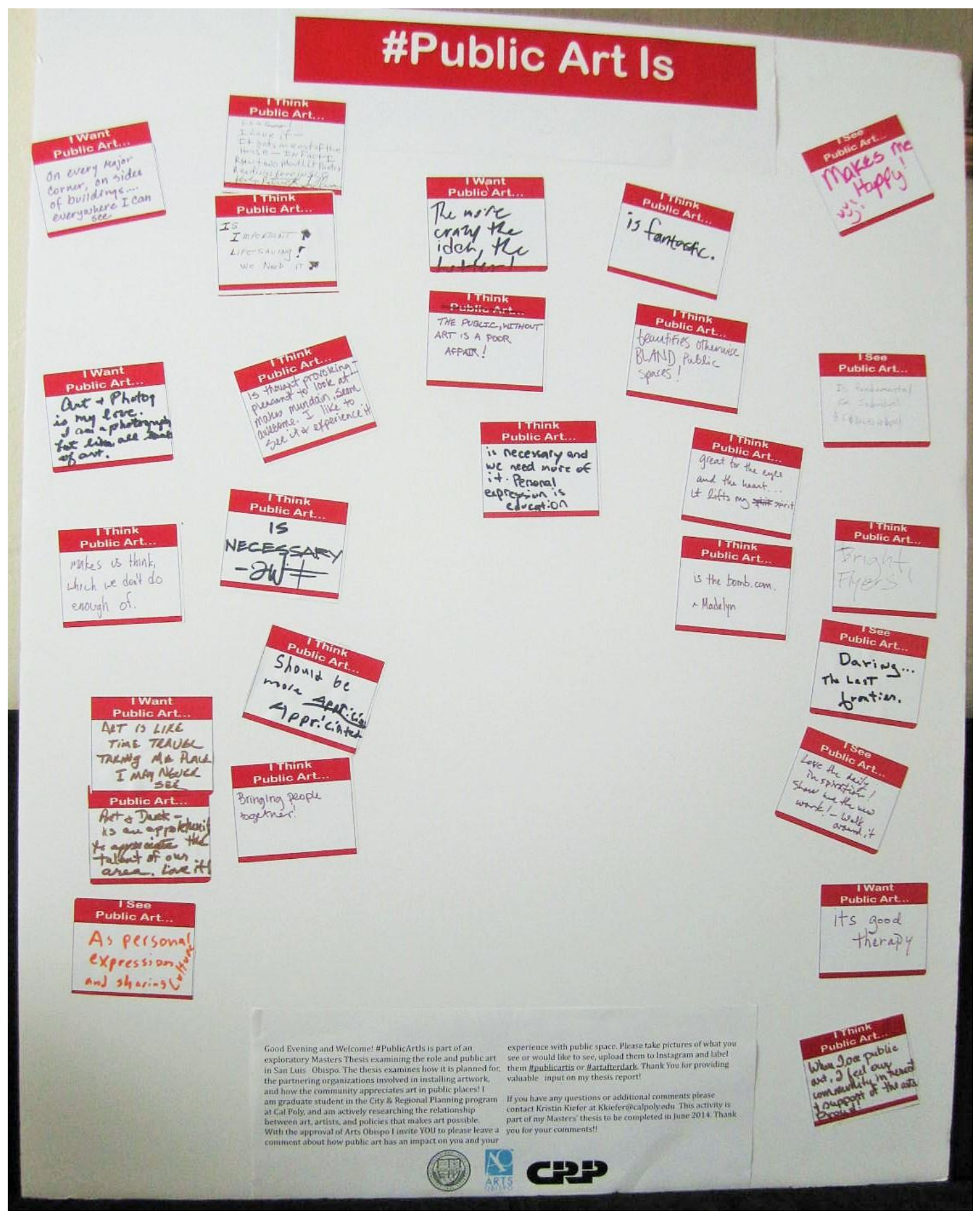


Appendix 2: Tabulations of All Responses from \#PublicArtIs Activity

\begin{tabular}{|c|c|}
\hline \multicolumn{2}{|c|}{ Community as a theme } \\
\hline is what makes a city a COMMUNITY & it inspires community unity \\
\hline $\begin{array}{l}\text { is an important part of any } \\
\text { community. }\end{array}$ & as a community connection. \\
\hline $\begin{array}{l}\text { Is vital to community. Uniting one } \\
\text { another and represeting that } \\
\text { moment in time. }\end{array}$ & $\begin{array}{l}\text { As an expression of how I feel } \\
\text { or see something that ma be } \\
\text { of value to me or my } \\
\text { community. }\end{array}$ \\
\hline puts an Individual into a Community & $\begin{array}{l}\text { as a representation of our } \\
\text { community }\end{array}$ \\
\hline $\begin{array}{l}\text { is good for the soul of our } \\
\text { community }\end{array}$ & to represent my community:) \\
\hline $\begin{array}{l}\text { A reflection of who we are as a } \\
\text { community }\end{array}$ & as a piece of our community. \\
\hline $\begin{array}{l}\text { is an awesome way to spread } \\
\text { creativity } \& \text { beauty to the } \\
\text { community! }\end{array}$ & The life blood of a town \\
\hline provides happiness to a community. & As a place to gather \\
\hline $\begin{array}{l}\text { (is) essential to a healthy life and a } \\
\text { strong community. }\end{array}$ & gathering place \\
\hline is a reflection of the community & $\begin{array}{l}\text { Brings me and my friends } \\
\text { together }\end{array}$ \\
\hline enriches a community. & $\begin{array}{l}\text { is fundamental for the } \\
\text { individual and the collective. }\end{array}$ \\
\hline $\begin{array}{l}\text { As part of us all, a community } \\
\text { sharing a unique vision }\end{array}$ & $\begin{array}{l}\text { as a creative outlook that can } \\
\text { involve the community }\end{array}$ \\
\hline $\begin{array}{l}\text { must include all the diverse parts of } \\
\text { a community. }\end{array}$ & $\begin{array}{l}\text { should be representative of } \\
\text { the area and always be } \\
\text { respectful. }\end{array}$ \\
\hline $\begin{array}{l}\text { should play a larger role in our } \\
\text { community. }\end{array}$ & $\begin{array}{l}\text { in collaboration, as social, not } \\
\text { limited to visual art. }\end{array}$ \\
\hline makes a community vibrant. & $\begin{array}{l}\text { as personal expression and } \\
\text { sharing cultue. }\end{array}$ \\
\hline $\begin{array}{l}\text { When I see public art, I feel our } \\
\text { community in the truest and } \\
\text { support of the arts. Proud! }\end{array}$ & $\begin{array}{l}\text { to be representative of } \\
\text { culture }\end{array}$ \\
\hline to reflect the community. & $\begin{array}{l}\text { Everywhere. In conversation, } \\
\text { movement, sidewalks, } \\
\text { buildings, food, all ages, all } \\
\text { aspects of community. }\end{array}$ \\
\hline
\end{tabular}

\begin{tabular}{|c|c|}
\hline \multicolumn{2}{|c|}{ Expression as a Theme } \\
\hline is expression & $\begin{array}{l}\text { (as) impressions and } \\
\text { expressions. }\end{array}$ \\
\hline $\begin{array}{l}\text { is an expression of us } \\
\text { today }\end{array}$ & $\begin{array}{l}\text { (to be an) expression of } \\
\text { beautiful thoughts. }\end{array}$ \\
\hline $\begin{array}{l}\text { As an expression of self \& } \\
\text { proof of bravery }\end{array}$ & $\begin{array}{l}\text { is an expression of love-no } \\
\text { right or wrong- just pure } \\
\text { enjoyment }\end{array}$ \\
\hline $\begin{array}{l}\text { Anything expressive of } \\
\text { the heart }<3\end{array}$ & $\begin{array}{l}\text { Freedom of expression and } \\
\text { desire. }\end{array}$ \\
\hline $\begin{array}{l}\text { is the greatest form of } \\
\text { expression }\end{array}$ & Self- Expression is Soul-Food \\
\hline $\begin{array}{l}\text { is an awesome expression } \\
\text { of humanity. }\end{array}$ & Is very inspirational \\
\hline $\begin{array}{l}\text { is cultural expression that } \\
\text { inspires }\end{array}$ & $\begin{array}{l}\text { as an opportunity for } \\
\text { everybody from all social } \\
\text { classes to enjoy art and its } \\
\text { expression. }\end{array}$ \\
\hline $\begin{array}{l}\text { as an expression of human } \\
\text { creativity. }\end{array}$ & $\begin{array}{l}\text { an enhancement to our } \\
\text { lives. Part of the food for our } \\
\text { souls. }\end{array}$ \\
\hline $\begin{array}{l}\text { expressing yourself for } \\
\text { others. }\end{array}$ & as telling a personal story \\
\hline $\begin{array}{l}\text { provides an outlet for self } \\
\text { expression. }\end{array}$ & $\begin{array}{l}\text { is necessary and we need } \\
\text { more it. Personal expression } \\
\text { is education. }\end{array}$ \\
\hline $\begin{array}{l}\text { (to be a) public } \\
\text { expression. }\end{array}$ & $\begin{array}{l}\text { A nonverbal way to } \\
\text { communicate }\end{array}$ \\
\hline $\begin{array}{l}\text { as an expression of } \\
\text { something not seen, yet } \\
\text { felt. }\end{array}$ & \\
\hline
\end{tabular}




\begin{tabular}{|c|c|}
\hline \multicolumn{2}{|c|}{ Emotions as a Theme } \\
\hline Necessary! Vital Awesome & $\begin{array}{l}\text { as a way to develop } \\
\text { consciousness of bliss }\end{array}$ \\
\hline A magical thing for all humans & $\begin{array}{l}\text { as people who look well and } \\
\text { are well and have always been } \\
\text { well. }\end{array}$ \\
\hline as beautiful. & $\begin{array}{l}\text { public art is a great way to } \\
\text { slow down the frantic pace of } \\
\text { daily life. Thoughtful, } \\
\text { creative, compassionate. }\end{array}$ \\
\hline $\begin{array}{l}\text { A way to share and beautify } \\
\text { our city and enlighten its } \\
\text { people }\end{array}$ & $\begin{array}{l}\text { As inspiring; real glimpes of } \\
\text { souls. }\end{array}$ \\
\hline brings beauty to the city. & $\begin{array}{l}\text { as an inspiration for the artist } \\
\text { in everyone. }\end{array}$ \\
\hline $\begin{array}{l}\text { European- inspiring, moving, } \\
\text { beautiful! }\end{array}$ & $\begin{array}{l}\text { to inspire the end-user in a } \\
\text { meaningful way. }\end{array}$ \\
\hline $\begin{array}{l}\text { that's interesting \& beautiful } \\
\& \text { unique }\end{array}$ & is inspiring. \\
\hline $\begin{array}{l}\text { to show how beautiful the } \\
\text { world is. }\end{array}$ & to be meaningful! \\
\hline ...is bold. Unexpected. & to have more meaning \\
\hline $\begin{array}{l}\text { is important! It gives us a } \\
\text { moment of joy, a thought as } \\
\text { we walk around town. }\end{array}$ & Is underappreciated \\
\hline is unique & as an expression of one love. \\
\hline $\begin{array}{l}\text { is badass. How can you not } \\
\text { love music, art, and free } \\
\text { drink. }\end{array}$ & shifting/ changing. \\
\hline is awesome & (as a) true reflection. \\
\hline ROCKS! & $:)$ \\
\hline is natural & should make me smile :) \\
\hline is personal. & Public Art brings people joy! \\
\hline is free (like freeing?) & (as being) interesting and fun! \\
\hline is cultural. & is FUN! \\
\hline is wonderful. & and it makes me hapy. \\
\hline $\begin{array}{l}\text { makes everything pretty and } \\
\text { gives the environment } \\
\text { personality. }\end{array}$ & $\begin{array}{l}\text { To make me happy and } \\
\text { excited }\end{array}$ \\
\hline (as) memory. & sometimes too gritty \& awful \\
\hline is fantastic. & to be diverse $\&$ unique \\
\hline bright fylers. & extra nice with a fine wine! \\
\hline as daring... the last frontier. & $\begin{array}{l}\text { is so much of why I love Art } \\
\text { After Dark. }\end{array}$ \\
\hline $\begin{array}{l}\text { Expands your mind. Brings } \\
\text { out a creative spirit in } \\
\text { viewers }\end{array}$ & Try it yourself at home! \\
\hline $\begin{array}{l}\text { moment by moment } \\
\text { enchantment }\end{array}$ & $\begin{array}{l}\text { Public Art is in the eye of the } \\
\text { beholder. Art After Dark rocks! }\end{array}$ \\
\hline Great & (as being) whimsical. \\
\hline Vibrant & to excite me! \\
\hline the more crazy the better. & as exciting \\
\hline magnanimous. & to surprise and challenge. \\
\hline 62 "Emoti & al" responses \\
\hline
\end{tabular}

\begin{tabular}{|c|c|}
\hline \multicolumn{2}{|c|}{\begin{tabular}{|r|} 
Action as a theme \\
\end{tabular}} \\
\hline Art fills a space & is necessary. \\
\hline brightens a space & is Needed. \\
\hline $\begin{array}{l}\text { beautifies otherwise bland } \\
\text { public spaces! }\end{array}$ & (is) essential \\
\hline $\begin{array}{l}\text { as an improvement to } \\
\text { otherwise dull surroundings }\end{array}$ & is extremely important! \\
\hline $\begin{array}{l}\text { leads to a sense of place. A } \\
\text { destination }\end{array}$ & $\begin{array}{l}\text { is important! It is life } \\
\text { saving. We need it! }\end{array}$ \\
\hline (makes) a sense of place. & $\begin{array}{l}\text { should be more } \\
\text { appreciated. }\end{array}$ \\
\hline to welcome outsiders & $\begin{array}{l}\text { Reminds me there's more } \\
\text { than the } 8 \text { hour job }\end{array}$ \\
\hline $\begin{array}{l}\text { shuld make you proud of } \\
\text { your hometown. }\end{array}$ & A job creator \\
\hline $\begin{array}{l}\text { I love it! It makes me proud } \\
\text { to be here. }\end{array}$ & $\begin{array}{l}\text { (is) paid for with tax } \\
\text { money }\end{array}$ \\
\hline (is) alive! & is in need of good subsidy \\
\hline $\begin{array}{l}\text { is a great importance to the } \\
\text { visual. }\end{array}$ & As educational \\
\hline brings people together. & $\begin{array}{l}\text { and I am greatful for ART } \\
\text { in schools }\end{array}$ \\
\hline $\begin{array}{l}\text { every town needs public art } \\
\text { to feed the soul. }\end{array}$ & $\begin{array}{l}\text { is street performance, } \\
\text { installations, \& sculpture. }\end{array}$ \\
\hline $\begin{array}{l}\text { is an intentional object } \\
\text { placed in the public to } \\
\text { express a feeling, belief, or } \\
\text { sentiment. }\end{array}$ & $\begin{array}{l}\text { like the electric box } \\
\text { paintings }\end{array}$ \\
\hline $\begin{array}{l}\text { love the daily inspiration! } \\
\text { Show me the new work!- } \\
\text { walk around it. }\end{array}$ & $\begin{array}{l}\text { Cambria's scarecrow feet } \\
\text { and Chris' Market are } \\
\text { wonderful examples. }\end{array}$ \\
\hline is what keeps art alive & $\begin{array}{l}\text { as an enjoyable evening } \\
\text { event }\end{array}$ \\
\hline $\begin{array}{l}\text { I love public art, especially } \\
\text { the Glass Shop! }\end{array}$ & statues \& graffiti \\
\hline $\begin{array}{l}\text { is a great way to show the } \\
\text { public hidden talents }\end{array}$ & in Chicago... the Bean \\
\hline $\begin{array}{l}\text { Art After Dark is an } \\
\text { opportunity to appreciate } \\
\text { the talent of our area. I love } \\
\text { it! }\end{array}$ & The Bean \\
\hline $\begin{array}{l}\text { should have a bigger role } \\
\text { for everyone. }\end{array}$ & Chicago Bean \\
\hline $\begin{array}{l}\text { (to be) more available for } \\
\text { all to participate in, not just } \\
\text { a selct few. }\end{array}$ & $\begin{array}{l}\text { Architecture (Frank } \\
\text { Gehry) }\end{array}$ \\
\hline $\begin{array}{l}\text { a good way to move the } \\
\text { currents of life. }\end{array}$ & To stay like it is today \\
\hline $\begin{array}{l}\text { To change my day (for the } \\
\text { better) }\end{array}$ & $\begin{array}{l}\text { something that catches } \\
\text { my eye. }\end{array}$ \\
\hline $\begin{array}{l}\text { is awesome! I }<3 \text { ART } \\
\text { \#SLOIFF }\end{array}$ & free, DIY, accessible \\
\hline $\begin{array}{l}\text { it makes me feel warm } \\
\text { inside. }\end{array}$ & to be EXPLORED! \\
\hline can save Ukraine! & to be enjoyed! \\
\hline (is) liberating $<3$ & (to be) interactive! \\
\hline is street dancing! & to be edible (?) \\
\hline beats private art. & $\begin{array}{l}\text { art \& photography are my } \\
\text { love. I am a photographer, } \\
\text { but I like all kinds of art. }\end{array}$ \\
\hline $\begin{array}{l}\text { is a gas! I love it. It gets me } \\
\text { out of the house- In fact I } \\
\text { run } 2 \text { monthy poetry } \\
\text { readings here in SLO. }\end{array}$ & to be good therapy. \\
\hline $\begin{array}{l}\text { is great fo the eyes and the } \\
\text { heart... it lifts my spirit. }\end{array}$ & $\begin{array}{l}\text { Art is like time travel } \\
\text { taking me places I may } \\
\text { never see. }\end{array}$ \\
\hline 64 Action re & esponses \\
\hline
\end{tabular}




\begin{tabular}{|c|c|}
\hline \multicolumn{2}{|c|}{ Discussions as a Theme } \\
\hline $\begin{array}{l}\text { A portrayal of unique ideas, } \\
\text { feelings \& concepts }\end{array}$ & To create dialogue \\
\hline $\begin{array}{l}\text { Is something that shakes your } \\
\text { brain }\end{array}$ & Controversial \\
\hline $\begin{array}{l}\text { a display of emotions that } \\
\text { cannot be said in words. }\end{array}$ & $\begin{array}{l}\text { should challenge us to think } \\
\text { differently }\end{array}$ \\
\hline $\begin{array}{l}\text { (is) something unusal that } \\
\text { stimulates thought. }\end{array}$ & $\begin{array}{l}\text { As interactive and thought- } \\
\text { provoking }\end{array}$ \\
\hline mimes. & to be thought provoking \\
\hline $\begin{array}{l}\text { as an antidote to the Real } \\
\text { World. }\end{array}$ & $\begin{array}{l}\text { is thought provoking, pleasant } \\
\text { to look at, and makes the } \\
\text { mundain seem awesome. I like } \\
\text { to see it and experience it. }\end{array}$ \\
\hline (to be) Innovative & to be provocative. \\
\hline (is) invigorating. & $\begin{array}{l}\text { as a tool to represent the } \\
\text { public interest. }\end{array}$ \\
\hline can be very powerful. & $\begin{array}{l}\text { makes me take a second look } \\
\text { at where I am. }\end{array}$ \\
\hline $\begin{array}{l}\text { I think the public without art } \\
\text { is a poor affair. }\end{array}$ & $\begin{array}{l}\text { to challenge and inform my } \\
\text { world view }\end{array}$ \\
\hline $\begin{array}{l}\text { is cave painting vs alien } \\
\text { technology. }\end{array}$ & $\begin{array}{l}\text { makes us think, which we } \\
\text { don't do enough of. }\end{array}$ \\
\hline is essential for a full life. & $\begin{array}{l}\text { to make you stop, and that's a } \\
\text { good thing. }\end{array}$ \\
\hline $\begin{array}{l}\text { anything that stirs the } \\
\text { imagination and allows you to } \\
\text { go elsewhere in your mind. }\end{array}$ & to make me think and grow. \\
\hline to make a statement & as education you can learn. \\
\hline (to be) Life Inspiring. & $\begin{array}{l}\text { should be what the artist } \\
\text { wants within reason of taste. }\end{array}$ \\
\hline $\begin{array}{l}\text { to share anyone and } \\
\text { everyone's point of view. }\end{array}$ & (should be) within taste \\
\hline and I don't know what it is. & $\begin{array}{l}\text { Collective Memory = } \\
\text { Past/Heritage }\end{array}$ \\
\hline $\begin{array}{l}\text { as keeping the world civil } \\
\text { (peace sign drawing) }\end{array}$ & to be of better quality. \\
\hline & nses \\
\hline
\end{tabular}

\begin{tabular}{|c|c|}
\hline \multicolumn{2}{|c|}{ Where?! as a Theme } \\
\hline EVERYWHERE! & $\begin{array}{l}\text { Great. We need more of it more } \\
\text { often. }\end{array}$ \\
\hline EVERYWHERE! & should be increased \\
\hline EVERYWHERE! & (needs) more encourage (ment) \\
\hline EVERYWHERE! & to be supported more! \\
\hline EVERYWHERE! & $\begin{array}{l}\text { should be accessible and } \\
\text { eclectic. }\end{array}$ \\
\hline is everywhere. & $\begin{array}{l}\text { All over the place. Make it easy } \\
\text { to get involved. }\end{array}$ \\
\hline everywhere. & $\begin{array}{l}\text { to live everywhere so that it can } \\
\text { live in everyone's hearts. }\end{array}$ \\
\hline to be everywhere! & where art ought to be! \\
\hline everywhere I go:) & $\begin{array}{l}\text { Not common enough, but } \\
\text { appreciated (esp. by me!) }\end{array}$ \\
\hline $\begin{array}{l}\text { to be everywhere \& accessible } \\
\text { to all. }\end{array}$ & $\begin{array}{l}\text { when it is there we need MORE } \\
\text { and more often. }\end{array}$ \\
\hline as everywhere. & not enough! \\
\hline $\begin{array}{l}\text { in every aspect of day to day } \\
\text { interactions. }\end{array}$ & to be displayed in schools. \\
\hline $\begin{array}{l}\text { everywhere. The architecture } \\
\text { in SLO, the Art After Dark, } \\
\text { fashion, etc. }\end{array}$ & to be all over campus. \\
\hline all art is local. & at Cal Poly. \\
\hline $\begin{array}{l}\text { displayed around SLO. It adds } \\
\text { color to the town. }\end{array}$ & in all things. \\
\hline on everystreet in SLO! :) & In ALL this places! \\
\hline $\begin{array}{l}\text { on our streets, sidewalks and } \\
\text { buildings. }\end{array}$ & on every available surface. \\
\hline $\begin{array}{l}\text { on every major corner, on } \\
\text { sides of buildings... } \\
\text { everywhere I can see. }\end{array}$ & to be wherever there is space! \\
\hline when I don't expect it. & in more cities across America! \\
\hline $\begin{array}{l}\text { To be unexpected and } \\
\text { everywhere-accessible to all }\end{array}$ & MORE! \\
\hline is found in unexpected places. & in more places all the time. \\
\hline $\begin{array}{l}\text { is amazing. The more the } \\
\text { better }\end{array}$ & more! \\
\hline is available to all. & want more of it. \\
\hline \multicolumn{2}{|c|}{ I WANT PUBLIC ART } \\
\hline Public Art & t should be Responses \\
\hline
\end{tabular}

